DOI: https://doi.org/10.22235/rd.vi20.1873

\title{
Error evidente, culpa y tipicidad en las infracciones aduaneras
}

Evident mistake, guilt and typicality in the customs infractions

Erro óbvio, culpa e tipicidade em violações alfandegárias

\author{
Pablo González Bianchi ${ }^{1}$ \\ ${ }^{1}$ Universidad de la República \\ Orcid: http/ /orcid.org/0000-0002-8274-8498.
}

Para citación: González Bianchi, Pablo, Error evidente, culpa y tipicidad en las infracciones aduaneras, DOI: https://doi.org/10.22235/rd.vi20.1873 en Revista de Derecho $\mathrm{N}^{\circ} 20$ (dic. 2019): 91-157. ISSN 1510-3714, ISSN On line 2393-6193, 15-28

\section{Resumen:}

Las infracciones aduaneras son una especie de infracciones administrativas. A ellas son aplicables los principios generales del derecho punitivo. Sin embargo, tales infracciones tienen características distintivas, debido a las funciones especiales de la Administración de Aduanas y a institutos como la declaración en aduana, un error evidente (este último se dictaminó legalmente y con características y consecuencias analizadas a fondo por especialistas y tribunales en Uruguay y en Argentina). La ley aduanera punitiva, así como la ley tributaria, contemplan cierto número de sanciones. Esto se debe a la existencia de una determinación concreta del valor legalmente protegido. En los aspectos no contemplados, el régimen de infracciones aduaneras debe completarse con los conceptos y principios del derecho punitivo en general y del derecho penal, en particular, que han desarrollado los conceptos de culpabilidad, mala conducta intencional y tipicidad muy profundamente. Esto incluso cuando el legislador haya mantenido en el nuevo Código Aduanero Uruguayo rastros de la responsabilidad objetiva para ciertas infracciones. El error como medio de exclusión de culpabilidad, presenta particularidades teniendo en cuenta la existencia del concepto de error evidente 
en el Derecho aduanero. En este trabajo se procura desarrollar los conceptos mencionados y examinar ciertas infracciones aduaneras previstas en la ley local.

Palabras clave. error evidente, Código Aduanero, declaración de aduanas, valor legalmente protegido, hechos y error de la ley, fraude de valor, falsificación.

\section{Abstract:}

Customs infractions are a species of administrative infractions. To those infractions the general principles of punitive law are applicable. However, such infractions have distinctive features, due to the special functions of the Customs Authority and to institutes such as customs declaration, evident mistake (the latter legally ruled and with characteristics and consequences thoroughly analyzed by specialized scholars and courts in Uruguay and in Argentina). Punitive customs law, as well as tax law, has a certain number of penalties. This is due to the existence of a concrete determination of the legally protected value. In the non-regulated aspects, the customs infractions regime must be completed with the concepts and principles of the punitive law in general and the criminal law in which the concepts of guilt or willfully misconduct and typicality have been developed very deeply. This is even when the legislator has maintained in the new Uruguayan Customs Code traces of the objective responsibility in certain infractions. The error as a mean of exclusion of guilt, has certain particularities considering the existence of the concept of evident error in customs law. Here we intend to develop the mentioned concepts and examine certain customs infractions ruled in the local law.

Keywords: evident mistake, customs code, customs declaration, legally protected value, facts and law mistake, value fraud, counterfeit.

\section{Resumo:}

As violações aduaneiras são uma espécie de violações administrativas. Os princípios gerais da lei punitiva aplicam-se a eles. No entanto, tais infracções têm características distintivas, devido às funções especiais da administração aduaneira e institutos como a declaração aduaneira, um erro óbvio (este último foi governado legalmente e com características e analisados em profundidade por especialistas e tribunais no Uruguai e na Argentina). O direito aduaneiro punitivo, bem como a legislação tributária, prevê uma série de sanções. Isto é devido à existência de uma determinação específica do valor legalmente protegido. Nos aspectos não abrangidos, o sistema de infracções aduaneiras deve ser complementado pelos conceitos e princípios da lei punitiva em geral e penal, em particular, que desenvolveram os conceitos de culpa, má conduta 
intencional e letra típica muito profundamente. Isto é mesmo que o legislador tenha mantido traços de responsabilidade objetiva por certas infrações no novo código aduaneiro uruguaio. $\mathrm{O}$ erro como meio de exclusão da culpa apresenta particularidades em vista da existência do conceito de erro evidente no direito aduaneiro. Este trabalho procura desenvolver os conceitos acima e examinar certas violações aduaneiras previstas na legislação local.

Palavras chave: erro óbvio, Código aduaneiro, declaração aduaneira, valor legalmente protegido, factos e erro da lei, fraude de valor, falsificação.

Sumario: I. Introducción. II. El error evidente. III. El derecho sancionatorio. IV. Derecho penal y Derecho Sancionatorio Administrativo. Algunas comparaciones V. Examen de algunos tipos en el Derecho Aduanero Sancionatorio. VI. La culpa en el derecho sancionatorio. VII. Conclusiones sobre el error evidente en el Derecho Aduanero.

\section{Introducción}

\section{Algunos puntos de unión entre los temas objeto de este trabajo}

Los tres temas que dan título a este trabajo están interrelacionados. El error evidente, más allá de su recepción en otras ramas del derecho, tiene en el derecho aduanero particularidades que lo delimitan como un instituto propio de esta rama jurídica. El error, a su vez, es una causa de inculpabilidad. El concepto de culpa o reproche por infringir un deber de cuidado ha sido introducido en forma expresa en la legislación aduanera (art. 213.1 del Código Aduanero del Uruguay - CAROU - ley No. 19.276 de 19 de setiembre de 2014), juntamente con la exigencia del dolo, en relación con varias infracciones. Ello, más allá de que en la anterior legislación, no podía caber duda de que al menos la infracción de defraudación de valor, consagrada en el artículo 13 del decreto-ley No. 14.629 de 5 de enero de 1977 (en la redacción dada por el artículo 150 
de la ley No. 16.320 de $1^{\circ}$ de noviembre de 1992), se castigaba a título de dolo ${ }^{2}$. Y sin perjuicio de la discusión que se daba en su oportunidad sobre si el artículo 287 de la ley No. 13.318 consagraba una responsabilidad objetiva ${ }^{3}$.

La introducción de un claro régimen de responsabilidad subjetiva no puede prescindir del estudio del error como eximente de culpabilidad. Ello, sin perjuicio de desarrollar más adelante que el "error evidente" en el derecho aduanero no tiene las mismas características que en el resto del derecho sancionatorio. En efecto, por tratarse de un error cometido en la declaración aduanera o en ocasión de esta, el error evidente es susceptible de "autocorregirse" si se mira la declaración en su conjunto, con lo cual hasta se podría decir que, en tal caso, desaparece como tal. Alternativamente, la evidencia del error podría hacer del mismo un error inculpable, ya que no infringiría la diligencia media, y sólo podría tener relevancia si se adoptara el criterio de la culpa levísima, desterrado tanto del campo civil, penal y sancionatorio en general.

La tipicidad, finalmente, tiene una gran conexión con los conceptos anteriores. En primer lugar, porque la declaración aduanera -en la cual se produce el error- forma parte de la estructura típica de varias infracciones. Y, en segundo lugar, porque el examen del tipo infraccional, en su aspecto subjetivo, puede revelar que sólo se castiga la infracción correspondiente con el grado máximo de la culpa: el dolo; y sin que en este caso tenga cabida siquiera la consideración de si se cometió o no un error evidente, porque ello deviene irrelevante.

\section{El derecho sancionatorio general}

Se comenzará por algunas consideraciones sobre el error evidente, para luego retomar más adelante el análisis del concepto de derecho sancionatorio general, del cual el derecho sancionatorio aduanero es sólo una parte. Este tema merecerá además un desarrollo en forma conjunta con los conceptos de culpa y tipicidad.

El estudio de este escenario será de interés ya que otras ramas de derecho sancionatorio (penal, derecho sancionatorio general, derecho sancionatorio tributario) nos pueden

${ }^{2}$ Pablo González Bianchi, El valor en aduana -la valoración de las mercaderías en el sistema GAT/OMC (Montevideo: Universidad de Montevideo, 2003 - 2010), Volumen II, 281 y sgts.

${ }^{3}$ Rossana Ferrari, “La responsabilidad prevista en el art. 287 de la ley 13.318 Régimen represivo aduanero-, ¿es objetiva?”, Revista de Comercio Exterior y Aduana, No. 3 (1997): 69 . 
ayudar a delinear los conceptos de error, culpa y tipo, máxime cuando no existe en el CAROU una regulación exhaustiva del sistema infraccional. En efecto aspectos tales como la imputabilidad, la definición de dolo y culpa, las causas de justificación, las causas de inculpabilidad, la tentativa, las circunstancias agravantes o atenuantes, etc., no han merecido la atención del legislador. No sucede esto por ejemplo en el derecho argentino, cuyo código aduanero (CAA) reguló con profundidad los delitos e infracciones aduaneros, reconociéndoles a éstas un marcado carácter penal. No obstante, a través del juego del art. 861 impidió un salto al vacío en materia de aplicación de los principios generales del Código Penal, estableciendo un sistema hermenéutico cerrado, que sólo abre sus puertas a los principios generales del Derecho Penal general en el caso que el sistema propio no le pudiere dar solución, fuere de manera expresa o implícita ${ }^{4}$.

\section{El error evidente}

\section{La recepción del concepto de error evidente en el CAROU}

Al repasar en el CAROU la normativa que rige el régimen aduanero de importación, se advierte en el artículo 70 (inalterabilidad de la declaración de mercadería) la consagración del concepto de error evidente o imposible de pasar inadvertido. La declaración aduanera puede corregirse hasta el momento de la determinación de canal de verificación. Aún luego de ese momento puede corregirse si el error surgiera de la lectura de la propia declaración o de la lectura de la documentación

4 Enrique C. Barreira y Héctor G. Vidal Albarracín, La responsabilidad en las infracciones aduaneras, Revista La Ley, Sección doctrina, Buenos Aires (1989 - A): 932. El art. 861 del Código Aduanero argentino expresa: "Siempre que no fueren expresa o tácitamente excluidas, son aplicables a esta Sección, las disposiciones generales del Código Penal”. El artículo anterior (860) que es el primero de la Sección XII ("Disposiciones Penales") expresa que: "Las disposiciones de esta Sección rigen respecto de los hechos que en este Código se prevén como delitos e infracciones". 
complementaria $^{5}$ (y, adicionalmente, si el error no implica pérdida de renta fiscal o presunción de infracción aduanera) (art. 70.2 del CAROU).

La terminología que refiere a este tipo de error puede variar en la doctrina y en la legislación nacional y comparada, pero básicamente es la que señala el art. 70 del CAROU: error que surge de la mera lectura de la declaración (antes: "permiso"). Esto es, un error que surge en forma palmaria (clara, patente, manifiesta) de una lectura atenta de la declaración (permiso) o de la lectura de la documentación complementaria. Un concepto parecido se establece en el Código Aduanero de la República Argentina ${ }^{6}$.

\section{Antecedentes}

No se trata por cierto de un tema nuevo, pero de alguna manera, salvo un antecedente en materia de valoración, hoy derogado, es la primera vez que el concepto se expresa de manera tan clara.

Una de las condiciones para aceptar la solicitud de corrección de errores en la declaración aduanera, con posterioridad a la determinación de canal o nivel de control (la otra es que el error no implique pérdida de renta fiscal o presunción de infracción aduanera) es que "el error surgiera de la lectura de la propia declaración o de la lectura de la documentación complementaria" (art. 70.2.B.1 del CAROU); esta disposición tiene su origen en la nueva redacción dada al art. 249 de la ley No. 13.318 por el artículo 306 de la ley No. 18.719 de 27 de diciembre de 2010, por la cual se previó que la Dirección Nacional de Aduanas ("DNA”), por resolución expresa, autorizará la corrección de la declaración aduanera de mercadería, cuando así lo solicitare el declarante, a posteriori de la asignación de canal de verificación y siempre que el error sea involuntario, no implique pérdida de renta fiscal o presunción de infracción aduanera.

Ambas disposiciones (la vigente del CAROU y la derogada del art. 249 de la ley No. 13.318) parecen estar inspiradas en el Código Aduanero del MERCOSUR (“CAM"-

\footnotetext{
${ }^{5} \mathrm{NE}$ : Las cursivas incluidas por el autor han sido reemplazadas por negritas, debido a las exigencias del marcapeo SciELO UY.

${ }^{6}$ Pedro E. Fernández Lalanne, Comentarios al Código Aduanero. Dos Tomos. $2^{\mathrm{a}}$ Edición Actualizada (Buenos Aires: Guía Práctica del Exportador e Importador, 1985). La cita del texto corresponde al Tomo II, 123.
} 
Decisión del Consejo Mercado Común No. 27/2010)굴 cuyo artículo 43, luego de señalar la inalterabilidad de la declaración aduanera (art. 43.1), estableció que, sin perjuicio de lo anterior, la Administración Aduanera podrá autorizar la rectificación, modificación o ampliación de la declaración registrada cuando la inexactitud formal surgiera de la lectura de la propia declaración o de la lectura de la documentación complementaria.

En todos estos casos de error, la solicitud espontánea de rectificación por parte del declarante es admisible en tanto no se hubiera iniciado un procedimiento de fiscalización por parte de la aduana.

Finalmente, todas las disposiciones citadas anteriormente reconocen su fuente en la legislación argentina. En efecto, el CAA, en sus artículos 225 y 332 (destinos aduaneros de importación y exportación, respectivamente), autorizan la rectificación, modificación o ampliación de la declaración aduanera, entre otras condiciones, cuando la inexactitud fuere comprobable de su lectura o de la de los documentos complementarios anexos a él. Y el artículo 959 del CAA reitera un concepto similar en sede de la infracción de declaración inexacta, al indicar que en cualquiera de las operaciones o de las destinaciones de importación o exportación, no será sancionado el que hubiere presentado una declaración inexacta siempre que mediara alguno de los siguientes supuestos: "a) la inexactitud fuere comprobable de la simple lectura de la propia declaración (...)".

\section{Efectos del error evidente}

Además de la posibilidad de no hacer efectiva una sanción ante el error evidente, la doctrina ha puesto de relieve otro efecto de estos errores: impedir la configuración de una infracción aduanera, cualquiera sea ésta. En efecto, la existencia de los mismos no es apta para constituir infracción desde que no era posible que pudiesen pasar inadvertidos, ni en la lectura del permiso ni en la verificación, ni en la revisación. Los errores evidentes, imposibles de pasar inadvertidos y que surgen de la simple lectura de la declaración aduanera (de la revisión del documento y no de la verificación de las mercaderías) no configuran infracción aduanera alguna ${ }^{8}$. Esto es así desde larga data

\footnotetext{
${ }^{7}$ El CAM no tiene aún vigencia al no haber sido internalizado aún por la totalidad de los Estados Parte del MERCOSUR (entre ellos Uruguay).

${ }^{8}$ Ariosto González Cuñarro, "Diferencia de Valor", Revista de Comercio Exterior Año I, No. 4 (Enero 1977): 26-27; también del mismo autor: "Error aritmético y
} 
como lo señala González Cuñarro, haciendo referencia a resoluciones de la propia aduana, en las cuales se expresaba que el error no constituye infracción aduanera, desde que no era posible que pasase inadvertido en la inspección de Visturía o en la ulterior revisación de la Segunda Mesa de Contralor, postura que fuera compartida por el Juez de Hacienda, Carlos M. Larghero. El denominado en la antigua jerga aduanera como permiso mal leído es un caso más de error evidente que tiene que surgir de la propia lectura del documento y de los que la respaldan. Se trata de aquellos errores que no podían pasar desapercibidos en el supuesto de haberse leído bien el permiso 9 .

\section{Jurisprudencia nacional}

Así un primer ejemplo es el de los errores aritméticos. Dijo el Tribunal de Apelaciones en lo Civil de 1er. Turno:

Quedan pues excluidas aquellas omisiones o incorrecciones que no tengan entidad y revelen un mero error aritmético, pero inidóneo a los efectos de inducir en error al valorador (...) está claro que nadie puede haber tenido la intención de defraudar estableciendo en el mismo documento (formulario de la declaración de valor) el precio de cada una de las partidas, que sumadas son muy superiores al que se puso como total.

En el caso existió un error de hecho (error material aritmético o de cálculo) evidente o imposible de pasar inadvertido pues surgía del mismo documento (Declaración de Valor) que se agregaba con el permiso de importación ${ }^{10}$. Es de hacer notar que en la época que tuvo lugar este caso, la defraudación de valor se castigaba solamente a título

defraudación de valor - comentario a las sentencias No. 54 de 10 de agosto de 1981 del Juzgado Letrado de Aduana de 1er. Turno y sentencia del TAC $1^{\circ}$ de 7 de junio de 1982”, La Justicia Uruguaya, tomo 85, caso No. 9758, 61- 68; con numerosas citas de doctrina.

${ }^{9}$ Ariosto González Cuñarro, "La declaración aduanera de las mercaderías en los países del MERCOSUR y en la Unión Europea”, Revista Tributaria, Tomo XXXIII, Número 194, (setiembre-octubre 2006): 609-610. Este trabajo fue publicado también en la Revista de Estudios Aduaneros del Instituto Argentino de Estudios Aduaneros, No. 17, Año XVII, Buenos Aires (Años 2005 y 2006): 55-74.

10 Sentencia del Tribunal de Apelaciones de 1er. Turno de 7 de junio de 1982 (Marabotto - Uriarte, R. - Olmedo - Clavijo), citada en nota al pie No. 8, con comentario de Ariosto González Cuñarro. 
de dolo, actitud subjetiva que se requería expresamente en la ley (artículo 13 del decreto-ley No. 14.629 de 5 de enero de 1977 en su redacción original). Así, el error aritmético evidente hacía desaparecer el dolo.

Un segundo ejemplo de error evidente -analizado por nuestra jurisprudencia- es haber dejado constancia en un ítem del certificado de origen (en cuya confección se toma en cuenta la factura) de una mercadería diferente a la de la factura, aunque igual en su cantidad o valor (error que se había originado en la digitación de un código erróneo al confeccionar el certificado: se debió haber digitado el código 100042 y se digitó el código 10042), por lo que en vez de aparecer -en el certificado de origen- 1.280 unidades de la mercadería "X" con un valor de U\$S 3.264, aparecían 1.280 unidades de la mercadería "Y" con el mismo valor. Resultaba además que la mercadería correcta aparecía no sólo en la factura sino también en el packing list, y así había sido declarada en el DUA. Dijo el TAC $2^{\circ}$ en sentencia de 20 de marzo de 2013:

(...) el error formulado, de escasa relevancia y sencillamente subsanable, no puede, de acuerdo con criterios de razonabilidad y lógica media, traer una consecuencia sumamente gravosa; no existiría una proporcionalidad entre la infracción y la sanción...No sería oportuno sancionar a quien digita un número equivocado en el certificado, en el DUA o cualquier otro documento.

Con mayor precisión aún, lo que se trató en el caso fue si el error padecido era formal o no, conforme a las disposiciones del Reglamento de Origen del MERCOSUR, pronunciándose el Tribunal en el sentido de que se trató de un error formal.

Un tercer tipo de error evidente, no punible, en posición pacíficamente aceptada por nuestra jurisprudencia, lo constituyen los errores al señalar la moneda de la operación. Ha sucedido en varias oportunidades en que la factura viene expresada en Euros, y que en el DUA se indican -por error- dólares, con lo cual la base de tributación disminuye. Es un caso de error evidente, desde que, como se verá más adelante, la factura es un documento complementario que acompaña la declaración y, por tanto, de la consideración de la declaración como un todo, debe inferirse la evidencia del error, que por otra parte era detectable mediante la sola lectura de la documentación.

Otros ejemplos en los cuales es admisible la corrección son brindados por Rosello ${ }^{11}$ : corrección de las marcas y números manifestados en la declaración, cuando con ella no

${ }^{11}$ Hugo M. Rosello, "Declaración aduanera de las mercaderías", La Aduana Uruguaya No. 735, Año LVI, Montevideo (diciembre 1969): 3491-3495. 
se elimina ninguno de los elementos que integran la declaración, pues sólo se invierte el orden con el que se ha establecido el número de bultos; la corrección es procedente cuando con ella se pretende completar la declaración efectuada o salvar algún vacío o insuficiencia de la misma, sin pretender cambiar o modificar dicha declaración; autorización de la unidad de aforo (moneda) mal declarada o establecida en forma distinta a la fijada por el arancel; cuando el error debió ser subsanado en la lectura no constituye infracción aduanera.

\section{Jurisprudencia argentina}

En cuanto a la jurisprudencia argentina, en un fallo del Tribunal Fiscal se analizó una declaración en la cual se describía al producto como "pilas de manganeso"; empero, para identificarlas, se puntualizó que las pilas eran del tipo "UM-1” y "UM-3”, que son denominaciones utilizadas por la Aduana, y que indican otro tipo de pilas: eléctricas, secas comunes, que son las que en definitiva se constataron en la verificación del despacho. Dijo el Tribunal Fiscal:

Que siendo ello así, es evidente que se está en presencia de una manifestación dual y por consiguiente el vista interviniente debió haber pedido las aclaraciones pertinentes (...) Que a mayor abundamiento, surgiendo de la lectura de la manifestación comprometida las descripciones antes señaladas, debió haberse advertido que al expresarse que las pilas eran de óxido de manganeso y decirse después que eran de los tipos UM-1 y UM-3 se configuraba el error evidente e imposible de pasar desapercibido que según reiterada jurisprudencia de esta misma Sala (...) es aquel que surge de la sola manifestación comprometida en la documentación aduanera pertinente, sin necesidad de que ocurra el acto de verificación, para su conocimiento por la autoridad aduanera, ni tampoco su confrontación con la documentación complementaria.

Y correspondía, en consecuencia, la absolución en los términos del art. 1057 de las ordenanzas de aduanas $^{12}$ (el destacado no está en el original).

En la sentencia del Tribunal Fiscal (Sala "G") de 23 de mayo de 2013, Expediente $N^{\circ}$ 22.663-A, se trató de una exportación con destino al territorio aduanero especial de

${ }^{12}$ Causa: González Efren R. y otra, Tribunal Fiscal de la Nación, Sala C, expte. 8.503, 2 de setiembre de 1971. Publicada en Derecho Aduanero, T. IV: 459-462. El artículo 1057 citado de las Ordenanzas de Aduana es el antecedente del art. 959 a) del Código Aduanero. 
Tierra de Fuego. El exportador solicitó el pago de reembolsos por la exportación. De la lectura del Permiso de Exportación surgía de que el exportador y el importador era el mismo, por lo que, no siendo una operación a título oneroso, no correspondía el pago reclamado. El Tribunal entendió que la declaración no contenía datos erróneos, sino la sola formulación de reclamo improcedente, improcedencia que surge de la propia declaración aduanera de la que resulta que el importador y el exportador son la misma persona jurídica. Que en la medida en que la contradicción surja de la simple lectura de la declaración, la no punibilidad de esas declaraciones se fundamenta en el art. 959, inc. a) del Cód. Aduanero. El Tribunal observó que las declaraciones que contienen contradicciones no pueden considerarse verdaderas, ni tampoco inexactas, salvo que la calificación de inexacta se refiera a sólo una parte de la declaración y no a la parte que la contradice. Considerada como un todo, la declaración contradictoria no puede calificarse de exacta o incorrecta. Justamente la contradicción interna de la declaración torna comprobable la inexactitud parcial por la simple lectura de la propia declaración. En la misma sentencia, el Tribunal adujo también que la C.N.F.C.A.F., Sala III, 09/08/1994, en los autos "Cosméticos Avon S.A.C.I.", consideró en el caso de manifestaciones comprometidas en que dos o más partes de su contenido resultan lógicamente incompatibles entre sí, que la declaración es contradictoria, y, por no poder calificarse de verdadera o falsa, correcta o errónea, no constituye infracción punible. También resulta aplicable al caso - dijo el Tribunal- la doctrina de la CSJN recaída en la causa "Megsa SACI", el 15-9-1987, similar a la presente, en la que se resolvió acerca del alcance de la declaración inexacta tipificada en el inc. a) del art. 954 del Código Aduanero con relación a la declaración en el permiso de embarque del beneficio que en concepto de estímulos a la exportación establecía el decreto 1691/87. La Corte en el considerando $6^{\circ}$ señaló "que el art. 954 inc. a) del Código Aduanero y el art. 10 del decreto 1691/87 requieren para la viabilidad de la sanción que prevén la configuración de una declaración inexacta o falsa manifestación relativa a las distintas operaciones de importación o exportación, cuyo alcance no resulta susceptible de extender a otras o inexactitudes manifestaciones que en su integración material, no resultan punibles dada la descripción literal del precepto, pues lo contrario vulneraría los principios del derecho penal que resultan aplicables en virtud de la naturaleza sanción examinada (Fallos 288:356; 290/202)”. Y finalmente el Tribunal expresó que teniendo en cuenta que la acción típica del art. 954, ap. 1, inc. a) del Cód. Ad. consiste en efectuar ante el servicio aduanero una declaración respecto de las destinaciones de importación o exportación 
que difiera con lo comprobado por la Aduana, y que produzca o pueda producir un perjuicio fiscal, cabe concluir que no se verifican en autos tales extremos por lo que no puede sostenerse la comisión de la infracción tipificada en el citado artículo.

El Tribunal Fiscal del vecino país también ha dicho que la contradicción que encierra una declaración de este tipo, impide calificarla como verdadera o falsa. Es de aplicación el artículo 959 inciso a) del CAA, que establece que no será sancionado el que hubiere presentado una declaración inexacta en cualquiera de las operaciones o destinaciones de exportación o de importación cuando "la inexactitud fuere comprobable de la simple lectura de la propia declaración...”; lo que según el Tribunal: “....encuadra exactamente en los casos de autos. No puede dejar de destacarse que el servicio aduanero tuvo a su alcance todos los elementos para advertir la contradicción señalada, en cuanto surgía de la propia declaración comprometida, por lo que pudo y debió detener el despacho de la mercadería y solicitar la pertinente aclaración y/o rectificación del permiso de embarque" ${ }^{\prime 13}$.

El artículo 959 del CAA, en sede de la infracción de declaración inexacta, exime de pena al declarante si la inexactitud fuere comprobable de la simple lectura de la propia declaración. En este último caso no se hace referencia expresa a los "documentos complementarios", por lo que la Corte Suprema de la República Argentina, a pesar de la opinión contraria del procurador general de la Nación (que conjugaba el art. 959 con el art. 322) entendió que la "simple lectura" abarcaba solamente a la declaración

13 Caso "PROALSA S.R.L.", Expte No 22.802-A, sentencia de 30.06.08 (Sala "F"). Antes, en el caso DEHESAS SRL, expediente 20814-A, de 11/09/2006, la misma Sala revocó la condena por considerar que la manifestación sobre inexistencia de una vinculación con el comprador extranjero se contradecía con el carácter de consignatario de la mercadería que revestía la misma firma exportadora y ello impedía considerarla como verdadera o falsa. El servicio aduanero tuvo a su alcance todos los elementos para advertir la contradicción señalada, en cuanto surgía de la propia declaración comprometida (Citada en Mario A. Alsina, Enrique C. Barreira, Ricardo Xavier Basaldúa, Juan P. Cotter Moine y Héctor G. Vidal Albarracín. Código Aduanero Comentado, 3 Tomos (completado y actualizado por Enrique C. Barreira, Ricardo Xavier Basaldúa, Héctor G. Vidal Albarracín, Juan P. Cotter (h.), Ana L. Sumcheski y Guillermo Vidal Albarracín (h.), (Buenos Aires: AbeledoPerrot, 2011). La cita de la sentencia figura en el Tomo III, página 410, nota al pie No. 184. 
considerada en sí misma, y no comprendía la lectura de los documentos complementarios $^{14}$.

\section{El alcance de la "declaración" en el derecho uruguayo. La documentación complementaria}

Nuestro derecho presenta una ventaja en relación con el tema anotado en el último párrafo del numeral anterior. Así, la lectura de la declaración debe comprender no sólo la declaración misma (el Documento Único Aduanero o DUA), sino también la de los documentos complementarios. La declaración es un todo que se compone no sólo de la declaración "pura", sino también de los documentos complementarios que deben acompañarse a dicha declaración y sirven de base a la misma. El art. 67.1 del CAROU establece que la declaración de mercadería deberá ser acompañada de la documentación complementaria exigible de acuerdo con el régimen solicitado conforme a la legislación aduanera. En adición a ello, y como norma fundamental, el artículo $4^{\circ}$ del decreto No. 312/98 establece: "Las declaraciones aduaneras deberán ser fidedignas y realizarse de conformidad a las informaciones obtenidas de los documentos presentados, los cuales a todos los efectos forman parte integrante de la misma" (el destacado no está en el original).

Ha dicho la doctrina en tal sentido que en Uruguay la declaración aduanera realizada es un acto "complejo", integrado no sólo por el DUA, sino también por los documentos que le sirven de base ${ }^{15}$, concepto que no puede reputarse modificado por el CAROU según lo hemos visto. Esto proyecta consecuencias muy importantes en materia de errores cometidos por el declarante, ya que la consideración de la "declaración informativa" en su conjunto puede revelar que dichos errores han sido cometidos de buena fe. Por ejemplo, el solicitante de la operación, al declarar el "valor en aduana" puede omitir involuntariamente agregar la suma correspondiente al pago del flete; no obstante, el pago por dicho concepto surge de la factura correspondiente, agregada en el "sobre" de la operación. Otro ejemplo de "error aritmético" es cuando en la "Declaración de valor" y en la factura se discriminan los valores de dos partidas de

${ }^{14}$ Alsina et al. Código Aduanero comentado, Tomo III, 410-411. La referencia es al fallo de la Corte Suprema de la Nación en el caso Petrobras Energía SA, fechado el 6 de marzo de 2014. Este criterio fue seguido en el fallo de la Cámara Contencioso Administrativo Federal -Sala 1- caso Ledesma SAAI, fechado el 13 de agosto de 2015 ${ }^{15}$ González Cuñarro, “La declaración aduanera”, 598. 
mercaderías (e inclusive en la factura se pone el valor total), pero en la Declaración principal se asigna al total de las mercaderías, el valor de una de las partidas.

Nuestra jurisprudencia ha seguido dicho criterio al establecer:

(...) se comparte con el recurrente, que resulta de aplicación las disposiciones del decreto 312/98 (artículo $4^{\circ}$ ) que establece que las declaraciones aduaneras no deben analizarse separadamente del documento de donde emana la información que en aquélla consta. Resulta totalmente compartible la jurisprudencia y doctrina convocadas por la demandada $(\ldots)^{16}$.

Por tanto, la consideración de la Declaración en su conjunto es susceptible de revelar el "error evidente o imposible de pasar inadvertido". Este tipo de errores, que surgen en forma obvia de la lectura de todos los elementos de la Declaración, revelan la ausencia de dolo o intención de engañar al Fisco (por su absoluta in-idoneidad para generar un “engaño"), siendo indicativos por lo contrario, de la buena fe del Declarante; y en definitiva, si este error hubiera sido susceptible de provocar una pérdida de renta fiscal, la situación deberá en todo caso resolverse en una reliquidación tributaria sin sanción ${ }^{17}$.

\section{El derecho sancionatorio}

Como se adelantaba al comienzo de este trabajo, resultará de sumo interés, a efectos de contextualizar el análisis del error evidente, y de los demás temas objeto de este trabajo, el examen de otras ramas sancionatorias y la posible unidad (y traslado de conceptos) de las mismas.

\section{Unidad del derecho sancionatorio}

\footnotetext{
${ }^{16}$ Sentencia del TAC $2^{\circ}$ de fecha 20 de marzo de 2013 (Sosa, Pérez Brignani, Franca). 17 González Cuñarro. "La declaración aduanera”, 609-610; Fernández Lalanne. Comentarios al Código Aduanero, T. II, 65; Ferro Carlos A. Ferro y Francisco M. Ferro. Código Aduanero comentado, 2a edición actualizada (Buenos Aires: Depalma, 1990), 739-740; Raúl González Berro. "Breve análisis de algunas situaciones relacionadas con las infracciones de valor", Revista de Comercio Exterior y Aduana FCU, No. 4 (1998): 72-73.
} 
Señalaba Sayagués Laso que, si se examina con criterio objetivo la realidad jurídica de la generalidad de los países, surge como verdad evidente que no hay diferencia de naturaleza entre los hechos que configuran delitos y faltas, como tampoco la hay entre tales hechos y los que constituyen infracciones administrativas. No obstante, el legislador los ha diferenciado formalmente en función de múltiples factores: entidad del hecho, orden jurídico vulnerado, necesidad de una represión más intensa o rápida, etc. El autor citado menciona el artículo 91 del Código Penal, en el que se establece que "no se reputan penas" las suspensiones disciplinarias de los funcionarios (inc. 2), ni las multas, arrestos y demás correcciones que impongan las autoridades administrativas en ejercicio de sus atribuciones (inc. 3 y 5), incluso en material fiscal (inc. 4). Y termina diciendo el maestro uruguayo: "En definitiva, la diferencia entre las infracciones y las sanciones penales y administrativas está dada por el derecho positivo"18.

Modernamente se ha abierto camino, al lado del Derecho Penal, la estructuración y delimitación del "Derecho Administrativo Sancionador". En efecto, ambas estructuras jurídicas serían ramificaciones de un género común o supra-concepto que es el poder punitivo del Estado, hasta el punto de que un mismo bien jurídico puede ser protegido tanto por técnicas administrativas como penales. La doctrina entiende que deberían aplicarse al derecho administrativo sancionador, los principios del derecho penal ${ }^{19}$. No existe en materia de infracciones administrativas una teoría general que permita

${ }^{18}$ Enrique Sayagués Laso, Tratado de Derecho Administrativo, 3 Tomos (Tomo I: $7^{\text {a }}$. Ed. puesta al día 1998 por Daniel H. Martins; Tomo II, 6ª edición puesta al día 1998; Tomo III, $1^{\text {a }}$ edición por Daniel Hugo Martins - FCU). La cita corresponde al Tomo I, No. 263, 355-357.

${ }^{19}$ Daniel E. Maljar. El derecho administrativo sancionador (Buenos Aires: AD-HOC, 2004), 71 y sgts.. Ver “Opinión de la Dirección” en Carlos E. Delpiazzo y Graciela Ruocco (directores), Tratado Jurisprudencial y Doctrinario (actos y contratos de la administración). 2 tomos (Montevideo: La Ley Uruguay, 2013); la referencia es al Cap. 16 (“Actos punitivos”), 149-150. Antonio J. García Gómez, La simple negligencia en la comisión de infracciones tributarias (Madrid: Marcial Pons, 2002), 19-20. También ver al respecto la reseña de opiniones doctrinarias en González Bianchi, El valor en aduana, Volumen II, No. 335, 263-266. 
apartarse de le teoría general del delito elaborada por la dogmática penal ${ }^{20}$. La doctrina ha examinado varios criterios presuntamente diferenciadores entre contravenciones (infracciones) y delitos, y ha concluido que ninguno de ellos permite establecer un límite tajante pues en todos los casos se encuentran excepciones que, en mayor o menor medida los desautorizan. En general las infracciones no suelen caracterizarse por gozar de un reproche social natural y espontáneo por parte de la población, pues están lejos de castigar violaciones en las que se encuentren en juego principios éticos universales ${ }^{21}$.

Es predominante la opinión de que la sanción en caso de una infracción administrativa tiene carácter punitivo y que entre ésta y la infracción penal no existen en lo esencial diferencias cualitativas y en muchos casos cuantitativas; esto hace que tratándose ambas de una manifestación del poder punitivo del Estado, deban o es deseable que sean sujetas a los mismos principios o límites, y en ese sentido los principios penales son un sistema de garantías ${ }^{22}$. En el mismo sentido, Berro habla de la existencia de un

20 Hugo López López. El principio de culpabilidad en materia de infracciones tributarias (Asociación Española de Asesores Fiscales. Navarra, Aranzadi - Thomson Reuters, 2009), 171.

${ }^{21}$ Barreira y Vidal Albarracín. “La responsabilidad en las infracciones aduaneras ”, 932933. Estos autores examinan cuatro posibles criterios diferenciadores: (i) el delito viola principios éticos universales y las contravenciones sólo ponen en peligro el orden social; (ii) las contravenciones se caracterizan por una inobservancia de los deberes establecidos en forma concreta, con el fin de preservar a los bienes jurídicos protegidos por las figuras penales mayores del peligro que implican las conductas así determinadas; (iii) el tipo de pena aplicable es diferente: los delitos se castigan con penas privativas de libertad y las infracciones con penas pecuniarias (multa o comiso) y (iv) ante las dificultades para encontrar una pauta de distinción, la misma debe ubicarse en la mayor o menor magnitud de la sanción aplicable con abandono definitivo de todo intento de encontrar diferencias ontológicas o de naturaleza jurídica entre ambos tipos de ilícitos.

${ }^{22}$ Diego Silva Forné, “Infracción fiscal, infracción administrativa y derecho penal”, en Derecho Penal, Hacienda y Administración Pública - Perspectivas en derecho nacional, internacional y comparado. Mariana Malet Vázquez y Diego Silva Forné, coordinadores (Montevideo: FCU, 2008), 35 y ss.; en el mismo sentido Federico Berro. “Criminalización de las infracciones tributarias", Revista Tributaria No. 144, Tomo XXV (mayo-junio 1998): 161-162; el autor expresa que no existe diferencia de esencia 
"Derecho Sancionatorio" general, que comprende tanto las sanciones administrativas como las sanciones a los ilícitos propiamente penales y que se rige por determinados principios, entre los cuales el autor citado destaca: legalidad, tipicidad, irretroactividad, jurisdiccionalidad, debido proceso, "non bis in ídem", inocencia del imputado, etc. ${ }^{23}$. Otros autores agregan: legalidad, proporcionalidad en la aplicación de sanciones, responsabilidad subjetiva, cuestionabilidad de los supuestos de responsabilidad solidaria o subsidiaria ${ }^{24}$.

Algunos autores entienden que no todas las sanciones administrativas son penas. Estas últimas son una especie dentro del género "sanciones" que comprende no sólo las sanciones "punitivas" sino también las "sanciones indemnizatorias" (v.g. los recargos por mora del artículo 94 del Código Tributario) ${ }^{25}$.

Esta distinción no es compartida por otros autores, que entienden que no son sanciones administrativas las que se adoptan con carácter resarcitorio o indemnizatorio, como por ejemplo las que imponen el restablecimiento al estado de cosas anterior -restitución de una cosa, restauración de un bien-, las de coacción administrativa directa, aplicadas para neutralizar situaciones de peligro (de carácter sanitario, urbanístico, ambiental, etc.), las multas coercitivas (similares a las astreintes del Derecho Civil) que tienden a vencer un incumplimiento, las cláusulas punitivas contractuales que se incluyen en los pliegos de

entre las sanciones o penas, cuyo fin es de castigo y no de reparación. Por tanto las multas impuestas en materia de infracciones tributarias o aduaneras, no se diferencian de las penas impuestas en materia de delitos penales.

${ }^{23}$ Federico Berro, Los ilícitos tributarios y sus sanciones, $2^{\mathrm{a}}$ Edición (Montevideo: FCU, 1995), 13-39. En el mismo sentido: Daniel Ferrere, "Derecho sancionatorio y procesal", en Jornadas de derecho tributario aduanero, Revista Tributaria No. 96 (Instituto Uruguayo de Estudios Tributarios), Tomo XVII (Mayo-junio 1990): 271-272; también: Raúl González Berro: "Las inhabilitaciones y suspensiones de los operadores privados en el Derecho Aduanero" en Memorias del Primer Encuentro Iberoamericano de Derecho Aduanero IIFA (Guadalajara, Jal. México - 2005): 116-122.

${ }^{24}$ Silva Forné, Infracción fiscal,... 38-41.

${ }^{25}$ Ramón Valdés Costa, Instituciones de Derecho Tributario (Buenos Aires: Depalma, 1992), 25. 
condiciones, etc. ${ }^{26}$. De todas formas, esta diferencia no deja de ser un tema semántico, ya que, con la debida aclaración, podría emplearse indistintamente el rótulo "sanción administrativa punitiva" o simplemente "sanción administrativa", a aquella sanción del orden administrativo que tenga una finalidad aflictiva, de pena, y que tenga identidad ontológica con la sanción propiamente penal.

En este sentido, la diferencia entre "sanción administrativa" (punitiva) y "sanción penal", podría considerarse puramente formal, y de ello es indicativa la norma ya citada del art. 91 del CP que, al establecer la exclusión de ciertas sanciones como penas, revela claramente que dicha exclusión es funcional ("no se reputan penas") y en nada afecta la naturaleza de "penas" de las sanciones excluidas 27.

\section{Tesis contraria a la unidad}

Parte de la doctrina de derecho administrativo ha expresado (contrariamente a las opiniones señaladas anteriormente) que existe una diferencia ontológica o de esencia entre el ilícito administrativo y el delito penal y se encuentra referida a los valores (éticos, formales y sociales) que imperan en una sociedad dada, por lo que las normas previsoras de infracciones administrativas y de delitos penales tutelan órdenes jurídicos diferentes. Ello permite, entre otras cosas, que en un mismo ordenamiento jurídico se aplique a un mismo sujeto y por un mismo hecho sanciones administrativas y penales.

${ }^{26}$ Silva Forné, Infracción fiscal,... 35-36. Ver también Zaffaroni, Raúl Eugenio, Alagia, Alejandro y Slokar Alejandro, Derecho Penal. Parte General (2 $2^{\mathrm{a}}$ ed. Buenos Aires: Ed. EDIAR, 2002), 214-218. Estos autores diferencian entre las "sanciones administrativas" aquellas que no son penas (medidas de coacción administrativa, sanciones reparadoras y restitutivas, etc.) y aquellas propiamente penales, como la multa penal. Al respecto, indican que si la coacción tiene contenido punitivo o penal, su control debe asignarse a las agencias jurídicas judiciales. Indican concretamente que “...el juez penal puede ser competente para imponer sanciones administrativas, pero la administración no puede imponer penas”. Esta afirmación tiene un particular interés en la medida en que, en el Derecho Administrativo uruguayo se imponen penas por órganos administrativos: inhabilitaciones dispuestas por el Banco Central del Uruguay o penas de multa impuestas por la Administración tributaria.

${ }^{27}$ Berro, Criminalización, 329; en el mismo sentido, Silva Forné, Infracción fiscal ...: 41. El codificador Irureta Goyena en las Notas Explicativas al proyecto, reconoce que la solución -para algunas de las situaciones excluidas- puede ser discutible. 
Principios que rigen el derecho penal, como derecho de defensa, presunción de inocencia, legítima defensa, estado de necesidad, se aplican en el derecho administrativo sancionatorio no por analogía con el derecho penal, sino porque son principios generales de derecho de jerarquía constitucional (art. 72 de la Carta). Otros principios, como el de la no retroactividad de la ley penal más benigna, fundado en razones de orden humanitario no serían por tanto aplicables a la infracción y a la sanción administrativa ${ }^{28}$.

Pero también es cierto que, aún en la posición que sostiene la diferente naturaleza de los ilícitos penales y administrativos, no se puede obviar la existencia de un conjunto de garantías constitucionales que inspiran el ejercicio de la potestad sancionadora de la Administración, muchas de los cuales han crecido jurídicamente en la órbita del Derecho Penal y por tanto, con todos los matices que se quieran, serán de alguna manera importadas hacia el Derecho administrativo sancionador. Aunque existan diferencias ontológicas entre infracciones administrativas y delitos penales, el Derecho público estatal no ha elaborado todavía una teoría útil sobre el ius puniendi del Estado que luego pueda aplicarse a cada una de sus manifestaciones, a diferencia de lo que sucede en el Derecho penal, de envidiable desarrollo, y cuyas técnicas y experiencia sería necio desaprovechar ${ }^{29}$. Es más, la doctrina ha afirmado que la tesis del supra concepto de ilícito, o si se quiere de la identidad sustancial de ambos ilícitos, penal y administrativo, es hoy, en definitiva, absolutamente dominante, aunque no falten testimonio de la postura contraria ${ }^{30}$.

\section{Teoría general del Derecho Penal y Derecho Sancionatorio Aduanero. Necesidad de la extensión}

En el escenario de esta unidad de las diversas ramas derecho sancionatorio, resulta claro que es en el derecho penal donde más se ha trabajado en el marco teórico, por lo cual,

28 Susana Lorenzo de Viega Jaime, "Naturaleza de la infracción y sanción administrativa", en Delpiazzo -Ruocco (Coords.), Tratado Jurisprudencial y doctrinario, Tomo II: 687-700. Más ampliamente y de la misma autora: Sanciones administrativas (Montevideo: Editorial BdeF, 1996), 36-43.

${ }^{29}$ García Gómez, La simple negligencia, 23-24, reproduciendo una opinión del autor español Alejandro Nieto.

30 Alejandro Nieto, Derecho Administrativo Sancionador (Quinta Edición totalmente reformada. Madrid: TECNOS, 2012 - reimpresión 2015), 126. 
los aportes doctrinarios realizados en este ámbito resultan de gran utilidad en el derecho sancionatorio general. En particular, en el derecho sancionatorio tributario se ha recurrido a la teoría general del derecho penal, y no existirían, en nuestro concepto obstáculos para obrar de la misma forma en el derecho sancionatorio aduanero. Esta labor debe realizarse con los debidos matices y adaptaciones que sean conformes con el particularismo del derecho aduanero, lo que puede generar algunas soluciones especiales propias de esta rama jurídica. Y, claro está, aplicando la dogmática penal en todos aquellos aspectos no previstos expresamente en la legislación sancionatoria aduanera.

La ausencia general de una teoría general se aprecia claramente en el CAROU. En su texto se enumeran y describen las diferentes figuras infraccionales y las sanciones correspondientes (arts.199 a 216), se determinan los responsables (arts. 218-219) y se establecen algunas disposiciones adicionales (actualización de multas -art. 216-, acuerdos de pago -art. 217-, concurso formal de infracciones -art. 220-, auto revisión art. 221-responsabilidad del Estado -art. 222-, prescripción -art. 223-). Pero está ausente en el CAROU una regulación general que comprenda aspectos como la imputabilidad, la definición de dolo y culpa, las causas de justificación, las causas de inculpabilidad, la tentativa, las circunstancias agravantes o atenuantes, etc., por lo que es lícito recurrir en muchos aspectos a la teoría general del delito, y también a los desarrollos -valiosos, aunque más escasos que en la dogmática penal- de la doctrina y jurisprudencia del derecho tributario. En este marco, no podemos dejar de destacar una innovación consistente en la recepción de la responsabilidad subjetiva: el art. 213 indica que las infracciones aduaneras de defraudación, defraudación de valor, desvío de exoneraciones y contrabando se imputarán a título de culpa o dolo; en tanto en las infracciones de contravención y de diferencia "no será admisible ninguna excusa fundada en la buena fe, en el error propio o ajeno o en la falta de intención de perjudica o defraudar al Fisco". En este último aspecto, se reitera la fórmula del derogado artículo 287 de la ley No. 13.318 de 28 de diciembre de 1964, sobre la cual una parte de la jurisprudencia entendía que consagraba una situación de responsabilidad objetiva, conclusión atenuada o al menos discutida por otra parte de la jurisprudencia y por la doctrina $^{31}$.

${ }^{31}$ González Bianchi, El Valor en Aduana, Volumen II, 271, nota al pie No. 1181. 
Por tanto, se podría aplicar, con las debidas precisiones que se indicarán, una definición de la infracción aduanera similar a la del delito penal, tal cual lo hace la doctrina tributarista. Así, la infracción aduanera sería una acción u omisión típica, antijurídica y culpable, añadiéndose a menudo la exigencia de que sea punible ${ }^{32}$. Debe existir por lo tanto: (i) una acción, o sea una conducta humana dominada o dominable por la voluntad; (ii) esta acción ha de ser típica, o sea debe coincidir con una de las descripciones de las infracciones enumeradas por el CAROU; (iii) debe ser antijurídica, o sea prohibida, lo que por regla general ya lo será con la tipicidad, aunque ello puede ser contradicho si existe una causa de justificación; (iv) la acción debe ser culpable, es decir ha de poderse hacer responsable de ella al autor, se le ha de poder reprochar, siempre que no existan causas de exculpación como el error de prohibición invencible $^{33}$. Hagamos notar que la culpa y el dolo impregnan al tipo. Así, luego de los aportes de Beling y Welzel se logró dar forma a la concepción penal que, considerando una teoría del delito comprensiva de la tipicidad, la antijuridicidad y culpabilidad, destaca la existencia en el tipo de un elemento objetivo y otro subjetivo; ubicándose en este último al dolo y la culpa. En esta sistemática, el tipo objetivo -o elemento objetivo del tipo- es la descripción de la conducta que el legislador ha entendido merecedora de reproche penal por afectar un bien jurídico preeminente para la comunidad ${ }^{34}$. En igual sentido se ha dicho que en la conducta típica la parte objetiva del tipo abarca el aspecto externo de la conducta, y la parte subjetiva del tipo se halla constituida siempre por la voluntad -consciente como en el dolo, o sin conciencia suficiente de su concreta peligrosidad, como en la imprudencia- y a veces por especiales elementos subjetivos (por ejemplo, el ánimo de lucro en el delito de hurto) ${ }^{35}$.

32 Claus Roxin, Derecho Penal General, Tomo I (Fundamentos. La estructura de la Teoría del Delito), traducción de la 2a. edición alemana (reimpresión), (Madrid: Thomson-Civitas, 2003), 193-194; Santiago Mir Puig, Derecho Penal. Parte General, $9^{\text {a }}$. Edición - 2a . reimpresión- (Montevideo - Buenos Aires, BdeF, 2015), 138. En la ley española se concibe la infracción tributaria como una acción típica, antijurídica, culpable y punible, al igual que el delito (Cfr.: López López, 171).

${ }^{33}$ Roxin, Derecho Penal General, 194-195.

${ }^{34}$ Raúl Guillermo López Carmelo, y Gabriel Darío Jarque, Curso de Derecho Penal (Universidad Nacional del Sur, Bahía Blanca, Argentina, 2004), 158.

${ }^{35}$ Mir Puig, Derecho Penal parte general, 229. 


\section{Derecho Penal y Derecho Sancionatorio Administrativo. Algunas comparaciones}

\section{Tipo y pre-tipo}

Más allá de esta posibilidad de extensión de la teoría penal al derecho sancionatorio administrativo, deben hacerse notar algunas diferencias entre ambos órdenes jurídicos. En este sentido se ha dicho que las normas penales no prohíben ni ordenan nada, sino que se limitan a advertir que determinadas conductas llevan aparejadas una pena. Los tipos sancionatorios administrativos, por el contrario, no son autónomos, sino que se remiten a otra norma en la que se formula una orden o una prohibición, cuyo incumplimiento supone cabalmente la infracción. Estas normas sustantivas constituyen por un pre-tipo, que condiciona y predetermina el tipo de la infracción. En otras palabras, el Ordenamiento Jurídico administrativo está integrado normalmente por mandatos y prohibiciones cuyo incumplimiento lleva aparejada una sanción (en sentido amplio), o sea unas consecuencias que de ordinario se señalan en un precepto distinto ${ }^{36}$. Estaríamos en presencia, en el campo del derecho administrativo sancionador, de dos tipos de normas diferenciadas: a) las que establecen un precepto o mandato; b) las que sancionan la violación de dicho precepto o mandato.

En materia penal, se ha afirmado también la existencia de un precepto y una sanción ${ }^{37}$. El precepto es ordinariamente, la descripción sintética de un modo de conducta; la sanción es la pena que ese modo de conducta acarrea consigo ${ }^{38}$. La opinión corriente consideraba que la acción del hombre consistía en violar o transgredir ese precepto. Según Binding, esta idea es impropia, pues los preceptos contienen sólo implícitamente una prohibición, pues lo que hacen es describir un modo de conducta, que es

\footnotetext{
${ }^{36}$ Nieto, Derecho Administrativo sancionador, 276-277.

${ }^{37}$ De hecho, nuestro Código Penal indica que para que una ley penal se considere tal, “...debe contener una norma y una sanción” (art. 1, inciso $2^{\circ}$ de dicho Código).

${ }^{38}$ Sebastián Soler, Derecho Penal argentino, Tomo I (6ª Reimpresión total, Tipográfica Editora Argentina, Buenos Aires, 1973), 110.
} 
precisamente el del delincuente. Este, pues, no viola la ley penal, sino algo que ésta implica. Así, el "apoderarse de una cosa ajena mueble", coincide totalmente con la acción del ladrón, y no es por tanto el principio vulnerado. Es algo así como el reverso del principio, de la norma que dice: "no robarás". Contra ésta, contra la norma, es contra lo que choca el delincuente al realizar la acción que el precepto meramente describe. El precepto penal no es por eso violado, al contrario, obrando conforme con él, es como se comete un delito, como se viola la norma. La ley que el delincuente transgrede, conceptual y casi siempre temporalmente precede a la ley que dispone la clase y modo de juzgamiento. Esto llevó a Binding al análisis de esas normas y a la afirmación de que casi todas ellas corresponden a otras ramas del derecho, si bien tienen como rasgo común el de ser públicas. Pero no resultando todas las normas expresamente contenidas en las disposiciones del derecho positivo, y no aceptando Binding que ellas estén contenidas sino sólo implicadas por el derecho penal, quedan las normas fluctuando en una vaga zona extra o supra legal en cuyo ámbito la sanción pierde importancia, conclusión que le ha valido enérgicas críticas al autor ${ }^{39}$, entre ellas la de Kelsen, quien sostiene que la doctrina de Binding olvida que el deber contenido en la ley penal es tan intangible o inviolable como el de la norma. Para Binding lo ilícito sería algo dado, anterior a la ley; la verdad es, por el contrario, que un hecho se reconoce como ilícito, cuando es el presupuesto para la voluntad del Estado que impone una consecuencia perjudicial al autor: pena o ejecución ${ }^{40}$.

Para Kelsen, en su concepción del derecho como orden coactivo, es errada la concepción de una norma sin sanción. Indica que para inducir a los hombres a conducirse de una manera determinada el derecho relaciona una sanción con la conducta contraria. La conducta que es la condición de la sanción se encuentra así prohibida, en tanto que la conducta que permite evitar una sanción es prescrita. Una norma jurídica puede ser formulada en términos que prescriban o prohíban una Inversamente, una conducta está jurídicamente prescripta sólo si la conducta opuesta es la condición de una sanción conducta determinada, pero esto no es indispensable. Así, la mayor parte de los códigos penales no prohíben expresamente la comisión de un crimen o delito. De igual modo, los códigos civiles no prescriben al deudor pagar su deuda; definen las distintas clases de contratos y prevén que, en caso de inejecución por una de

\footnotetext{
${ }^{39}$ Soler, Derecho Penal Argentino, Tomo I, 110-111.

${ }^{40}$ Soler, Derecho Penal Argentino, Tomo I, 111-112.
} 
las partes, el acreedor puede demandar ante un tribunal para que ordene le ejecución forzada de los bienes del deudor. Por el contrario -sigue diciendo Kelsen- encontramos leyes que prescriben una conducta determinada sin que la conducta contraria sea la condición de una sanción. En este caso estamos en presencia de una simple expresión de deseos del legislador que no tiene un alcance jurídico. Para que una norma pertenezca a la esfera del derecho es necesario que defina la conducta que constituye la condición de una sanción y determine esta sanción (la sanción es imprescindible para que la norma sea jurídica); por ejemplo: el que no cumple con el servicio militar debe ser condenado a una pena de dos a cinco años de prisión. Estamos aquí en presencia de una norma jurídica completa. Una norma que se limitara a imponer la obligación de hacer el servicio militar sería incompleta, dado que no indicaría cuál es la sanción en caso de violación de esta obligación. Por lo tanto, debe ser completada para convertirse en una verdadera norma jurídica. Kelsen llama norma primaria a la que establece la relación entre el hecho ilícito y la sanción, y norma secundaria a la que prescribe la conducta que permite evitar la sanción; pero una regla de derecho secundaria es de hecho superflua, pues supone la existencia de una regla de derecho primaria, sin la cual no tendría ninguna significación jurídica, y esta regla de derecho primaria contiene todos los elementos necesarios para la descripción de la norma jurídica completa ${ }^{41}$.

La concepción de Kelsen en el sentido de conceptuar a la norma jurídica como un acto coactivo imputado a una condición determinada (dado un hecho reprobable, debe ser la aplicación de una sanción) fue criticada por el jurista argentino Carlos Cossio. Este autor entiende que hay conducta en interferencia intersubjetiva tanto en la transgresión y aplicación de sanciones, como en el cumplimiento espontaneo de la prestación; toda sociedad descansa siempre sobre una base de armonía o de cumplimiento espontáneo de los deberes jurídicos respecto de la cual las transgresiones y la aplicación de sanciones son verdaderamente casos de excepción. La norma requiere desdoblar su estructura normativa separando la prestación debida por el sujeto obligado frente al sujeto pretensor de la sanción en caso de no cumplirse con la prestación debida, lo que se puede formular disyuntivamente: 1) dado un hecho en el tiempo, 2) debe ser, 3) una prestación, 4) por alguien obligado, 5) frente a un sujeto pretensor o ante alguien titular, 6) o, 7) en el caso de que no se cumpliera con dicha Prestación, 8) debe ser, 9) la

${ }^{41}$ Hans Kelsen. Teoría pura del Derecho (5a edición, Buenos Aires: EUDEBA, 1967), 76-78. 
aplicación de una sanción, 10) por un funcionario obligado, 11) por quien responderá frente a la Comunicad Pretensora o por pretensión de la Comunidad.

Cossio denomina endonorma al tramo de la norma jurídica compleja constituido por el acto lícito, teniendo en cuenta que es el núcleo desde el cual se despliega el principio ontológico de todo ordenamiento jurídico, según el cual la libertad es lo primero: todo lo que no está prohibido está permitido; y denomina perinorma al tramo de la norma constituido por el acto ilícito. De esta forma se reflejan adecuadamente los conceptos jurídicos de licitud e ilicitud (ineludibles en el campo del derecho), puestos que éstos se estructuran forzosamente en forma de disyunción contradictoria. Los dos términos del juicio disyuntivo unidos por la conjunción $o$ y no simplemente yuxtapuestos, tienen ambos un innegable valor ontológico: los dos aluden a realidades de conducta humana, que sólo difieren por su distinto sentido jurídico; mientras la endonorma menta la conducta que es lícita, la perinorma hace referencia al ilícito o entuerto ${ }^{42}$.

Siendo así, Cossio no considera que únicamente la norma primaria -que prescribe la sanción- tenga sentido ontológico. La norma secundaria -que prevé la prestación- no es en absoluto un mero recurso lingüístico, sino que va a estar, por lo menos en pie de igualdad con la norma primaria, y va a tener tanto sentido ontológico como aquella ${ }^{43}$. Se aprecia, por tanto, en el escenario planteado por Cossio de la estructura jurídica de la norma como un juicio disyuntivo, que la endonorma es el sector de ese juicio que en la teoría de Kelsen sería la norma secundaria, y la perinorma el sector de ese juicio que en la misma teoría sería la norma secundaria

${ }^{42}$ Citado por Enrique R. Aftalión, José Vilanova y Julio Raffo. Introducción al Derecho (5 edición, Buenos Aires, Abeledo Perrot, 2009), 413-414 y 419.

${ }^{43}$ Para superar lo que entiende como deficiencia en la teoría de Kelsen, Cossio entiende que debe darse como correcta estructura jurídica de la norma, una sola expresión que contempla tanto la transgresión y aplicación de la sanción, como la normación del deber jurídico o prestación (citado en Aftalión, Vilanova y Raffo, Introducción ... 413-414). Más ampliamente ver también Enrique C. Barreira, "La relación jurídica tributaria y la relación jurídica aduanera”, en Revista de Estudios Aduaneros, Instituto Argentino de Estudios Aduaneros No. 18 Año XVIII (Primer Semestre de 2007): 59-60; Aftalión, Vilanova y Raffo, Introducción ... 414-415 y 419. 
No es propósito de este trabajo profundizar más en la teoría de la norma jurídica ${ }^{44}$, sino simplemente señalar que en el derecho administrativo sancionador se advierte con más claridad esta doble estructura normativa, al estar diferenciado el pre-tipo del tipo, la norma secundaria de la norma primaria, la endonorma de la perinorma, según cuál sea la posición que se adopte. En tanto que, en el derecho penal, no existe propiamente una relación explícita de preceptos o mandatos, y aparece en forma más evidente el sector de la norma que Kelsen denomina norma primaria (que para dicho autor es la norma fundamental) y Cossio, perinorma.

Así, en consecuencia, el concepto de pre-tipo del derecho administrativo sancionador, o sea la norma que establece un precepto, coincide con el concepto de norma secundaria o endonorma. En el derecho penal, no existirían pre-tipos (al menos en forma explícita), sino solamente tipos, esto es normas primarias o perinormas. Los códigos penales no contienen una enunciación de normas secundarias y en todo caso dichas normas se deducen de las normas primarias: la norma (secundaria) que impone una obligación (no matarás) está implícita en la norma primaria, en tanto ésta castiga la conducta opuesta (matar). Ello, sin olvidar que, según la concepción de Kelsen, la norma secundaria aislada no sería una norma jurídica, pues carece de coactividad y estaría en un plano jus naturalista.

En el derecho administrativo sancionador, las cosas suceden por tanto de manera diferente que en el derecho penal. Por un lado, existen una serie de mandatos y prohibiciones contenidos en una o más normas secundarias (pre-tipos), cuyo incumplimiento lleva aparejada una sanción, prevista en un precepto diferente (norma primaria). La conclusión sería que el derecho administrativo sancionador está compuesto de normas sancionatorias, que se vinculan a otras tantas normas que establecen preceptos o mandatos, y cuyo incumplimiento es el que genera la aplicación de las normas sancionatorias. La vinculación de las normas sancionatorias con un elenco de otras normas que establecen preceptos es entonces una de las diferencias entre el derecho penal y el derecho administrativo sancionador.

\section{Tipos abiertos y tipos en blanco. El principio de "cobertura legal"}

${ }^{44}$ Al respecto puede leerse con provecho: Luis Martínez Roldán y Jesús A. Fernández Suárez, Curso de teoría del derecho (Barcelona: Ed. Ariel, 2a . edición, 1999), 114-140. Aftalión, Vilanova y Raffo, Introducción ... , cap. XIII, 395-450. 
La mayor separación de las normas primarias y secundarias en el derecho administrativo sancionador ha dado lugar a otra característica de este: la existencia de tipos abiertos o aún tipos en blanco, en mucho mayor medida que en el derecho penal.

Se ha afirmado, siguiendo la doctrina del Tribunal Constitucional español, que en el derecho administrativo sancionador el concepto aplicable es el de "cobertura legal" y no "reserva absoluta de ley" (como en el derecho penal), lo que significa -en el primer caso- que la exigencia de una ley formal es sólo para una descripción genérica de las conductas sancionables y la cuantía de las sanciones, pero con la posibilidad de remitir a la potestad reglamentaria la descripción pormenorizada de las conductas ilícitas. Ello conlleva que el principio de tipicidad sea menos riguroso, y se establezcan tipos abiertos o sea descripciones incompletas de las conductas sancionables, que pueden ser complementadas por otras normas a las cuales se remiten las primeras, siempre que no se restrinjan derechos fundamentales ${ }^{45}$.

El principio de "cobertura legal" en el derecho administrativo sancionador implica por tanto la existencia de tipos abiertos o aún tipos en blanco, con una mayor intensidad que en el derecho penal. Ello no implica, empero, una ausencia absoluta de tipicidad. La doctrina administrativista ha expresado que, si bien no puede pretenderse la previsión normativa de todos los hechos incriminables, no es menos cierto que debe existir al menos un grado mínimo de definición de la conducta punible La tipicidad exige una descripción legal de la conducta, que puede ser completada por el reglamento, a la que se conectará una sanción específica, esto es la señalada cobertura legal. Claro está que el reglamento sin cobertura legal es violatorio de la seguridad jurídica, y resultará ilegal por crear una sanción no prevista en la ley ${ }^{46}$.

Una ley en blanco no es un cheque en blanco que el Ejecutivo puede llenar a su gusto, sino una ley incompleta (por su contenido) o una ley de remisión (por su función) que, consciente de sus carencias, encomienda efectivamente al Reglamento la tarea de completarlas, aunque cuidándose de indicarle cómo. El Reglamento no suple los olvidos de la ley, sino que completa lo que ésta ha dejado de forma deliberada

${ }^{45}$ Graciela Ruocco, "Principios de legalidad, tipicidad y de prescripción en materia de actividad sancionatoria de la Administración", en Carlos E. Delpiazzo y Graciela Ruocco, Tratado Jurisprudencial y Doctrinario, 700-742 (especialmente: 717-719, 723, 727-729 y 739-742).

${ }^{46}$ Delpiazzo y Ruocco, Tratado Jurisprudencial y Doctrinario, Tomo I, 154-158 
solamente esbozado, o acaba lo que se ha dejado sin terminar, pero ya comenzado. En caso contrario sería inconstitucional. De ahí que se hable de colaboración y no de sustitución.

En el derecho administrativo sancionador el contenido de una ley en blanco comprende los siguientes elementos: a) regulación sustantiva de la materia, que no pretende ser exhaustiva; b) determinación de instrucciones, criterios o bases que resultan suficientemente expresivos como para que, a partir de ellos, pueda luego desarrollarse la normativa; c) una habilitación reglamentaria para que el Reglamento regule la materia penetrando en una zona reservada a la ley, sin exceder las instrucciones legales; d) una remisión al resultado de la colaboración reglamentaria que, en los términos dichos, se ha posibilitado u ordenado ${ }^{47}$.

Lo anterior coincide con el concepto de las leyes penales en blanco acuñado por la doctrina penalista, aunque en sede penal, el completar un precepto penal con un reglamento reviste un reproche mayor (con relación al principio de legalidad) que en sede del derecho sancionador administrativo. Así, dice la doctrina penalista que, en este tipo de leyes, si bien existe un precepto, el mismo es indeterminado, falto de concreción y debe por tanto ser complementado por una disposición posterior que le dé sentido, actualidad y concreción. En este tipo de leyes solamente queda fijada con exactitud invariable la sanción. Cuando la norma que integrará el blanco complementando el precepto es una norma de naturaleza legal, el problema no se plantea; pero alcanza una intensidad inusitada cuando se trata de llenar el blanco a través de una disposición de inferior rango normativo (decreto o resolución administrativa o reglamento de carácter general). Un ejemplo es la ley 17.016 de 1998 sobre tráfico ilícito de drogas, que prohíbe en definitiva las maniobras referidas al tráfico de las sustancias establecidas en determinados tablas y listados incorporadas a la propia ley. El artículo 15 de la ley dispone que el Poder Ejecutivo podrá modificar o ampliar el contenido de las listas y tablas, incluyendo o excluyendo sustancias, por lo que se está ante una típica ley penal en blanco, ya que el Poder Ejecutivo dispone en definitiva la materia de la prohibición

\footnotetext{
47 Nieto, Derecho Administrativo sancionador, 227-228. Los destacados están en el original.
} 
al introducir o excluir sustancias, y hasta que ello no ocurra el Juez no puede llenar el blanco (no es un tipo abierto) ${ }^{48}$.

Los tipos penales en blanco no deben confundirse con los tipos abiertos. En los primeros, no existe precepto determinado, en los segundos el precepto existe, sólo que el Juez tendrá una amplia gama de interpretaciones para establecer el contenido de la prohibición; por ejemplo, el artículo 162 del Código Penal, que prevé el delito de abuso de funciones en casos no previstos especialmente por la ley, cometido por un funcionario público que con abuso de su cargo "cometiere u ordenare cualquier acto arbitrario en perjuicio de la administración o de los particulares". Es un tipo abierto porque el delito consiste en "cometer actos arbitrarios con abuso del cargo", dependiendo del criterio del intérprete establecer, ante cada caso concreto, cuando se ha producido esa conducta específicamente establecida por la Ley ${ }^{49}$. En los tipos abiertos, la materia de la prohibición no está exhaustivamente descrita y se requiere un juicio positivo del juez para determinar la antijuridicidad. Si alguien presta un juramento falso, el juez sólo podrá afirmar la antijuridicidad, a pesar de la realización del tipo, una vez que haya comprobado afirmativamente: "La autoridad era competente para recibir el juramento" 50 . En los tipos abiertos, por tanto, no se describe exhaustivamente y en todos sus aspectos el objeto de la prohibición. En ellos ocurre que el tipo aún no es un indicio del injusto; por lo contrario, el injusto sólo puede comprobarse desde la perspectiva de la antijuridicidad mediante la verificación positiva de "elementos especiales de la antijuridicidad" (antes "elementos del deber jurídico").

Es importante hacer notar que todos los delitos imputables a título de culpa, es decir los delitos culposos son delitos de tipo abierto. En efecto, la mera lesión del bien jurídico carece de efecto indiciario de la culpabilidad, es necesario que el resultado esté conectado de manera adecuada y previsible con la acción. Por ese motivo, según

48 Miguel Langón Cuñarro, Manual de Derecho Penal Uruguayo (Montevideo: Ediciones del Foro, 2006), 79-80.

49 Langón, Manual .... 79-80. Soler, Derecho Penal ..., Tomo I, 121-122. Este autor indica, que la norma penal en blanco no cobra valor sino después de dictada la ley o reglamentación a que se remite, y para los hechos posteriores a ésta; mientras tanto dice Soler citando a Binding "...la ley penal es como un cuerpo errante que busca su alma".

${ }^{50}$ Siguiendo en esto a Welzel, citado por Roxin, Derecho Penal ..., 89-90. 
Welzel, el tipo de los delitos culposos es un tipo abierto. El efecto indiciario de la antijuridicidad sólo tiene lugar si el autor no ha puesto en su obrar la medida de dirección final exigida en la vida social para la evitación de lesiones de bienes jurídicos, o dicho brevemente: cuando no ha observado el cuidado objetivo exigido. Este deber de cuidado es un componente de la antijuridicidad; el juez debe comprobar su lesión antes de determinar la existencia de causas de justificación ${ }^{51}$.

Existiría en los tipos penales abiertos, lo que la doctrina de derecho administrativo ha catalogado como introducción en la definición del tipo de conceptos jurídicos indeterminados, cuya determinación discrecional debe resistir el test de razonabilidad ${ }^{52}$ (el subrayado no está en el original).

Finalmente, en el tipo cerrado, existe una descripción de todos los elementos que fundamentan el injusto, de tal modo que en el marco de la antijuridicidad sólo resta por examinar la ausencia de causas de exclusión del injusto. El tipo del homicidio, por ejemplo, es un tipo cerrado. Si una persona da muerte a otra, se dan en la realidad todos los elementos del tipo (la materia de la prohibición está exhaustivamente descrita), y no se requiere un juicio positivo del juez para determinar la antijuridicidad. A éste sólo corresponderá examinar si existieron causas de justificación que eliminen la antijuridicidad.

\section{Bien jurídico tutelado}

En nuestro concepto, la extensión de la dogmática penal resulta más sencilla en referencia a cierto sector de infracciones administrativas, particularmente a las infracciones fiscales y aduaneras, pero puede chocar con obstáculos en relación con otras infracciones administrativas. En materia infraccional aduanera y tributaria, podemos encontrar un número finito de infracciones, al igual que en el derecho penal. En cambio, en el derecho administrativo sancionador general, el repertorio de transgresiones es inagotable ${ }^{53}$. Al igual que en el derecho penal, no pueden existir en el derecho aduanero y tributario sancionador, más infracciones que las expresamente tipificadas. En este escenario, parece -en principio- más sencilla la extensión de los

\footnotetext{
${ }^{51}$ Citado por Roxin, Derecho Penal ..., 19-20.

52 Delpiazzo - Ruocco, Tratado jurisprudencial ...,158 (comentando una sentencia del Tribunal de lo Contencioso Administrativo).

${ }^{53}$ Maljar, El Derecho Administrativo ..., 190. Lo que también es destacado por Nieto, Derecho Administrativo ..., 151.
} 
principios del derecho penal (tomando además en cuenta que muchos de ellos son de raigambre constitucional) a esta sub-categoría del derecho administrativo sancionador. Pero, retomando lo que expusimos más arriba, entendemos que los conceptos y pautas señalados, que marcan una diferencia entre el derecho penal y el derecho administrativo sancionador, se desdibujan frente a dos ramas de este último que se han desprendido del derecho administrativo, cobrando autonomía o al menos cierto particularismo, como el derecho tributario material ${ }^{54}$, cuyo régimen de infracciones y sanciones permite una mayor integración con la dogmática penal, sin perjuicio claro está de ciertas especificidades derivadas de su autonomía; y lo mismo podría decirse en relación al derecho sancionatorio aduanero (régimen de las infracciones aduaneras). Estas ramas (derecho sancionatorio tributario y aduanero) se han desprendido del tronco del Derecho Administrativo, lo cual es explicable en la medida en que, como se dijo, han cobrado autonomía o al menos cierto particularismo. En el aspecto sancionador de estas ramas, el bien jurídico tutelado está más determinado, y cobra por ende más fuerza la necesidad de fijar claramente el elenco de las posibles infracciones y sus sanciones. En el ámbito tributario se constata más la identidad con el derecho penal, no sólo en cuanto a los bienes jurídicos protegidos, sino en los tipos objetivos y, en fin, en la constante emigración de figuras de uno a otro campo. El Derecho sancionador tributario, es primero sancionador y después tributario, con la peculiaridad añadida de que entre las infracciones de esta clase y los ilícitos penales existe una afinidad estructural que no es posible negar ${ }^{55}$ Lo mismo sucede con el régimen de infracciones y sanciones en materia aduanera, de características muy similares al Derecho sancionador tributario, en tanto contiene un elenco cerrado de infracciones aduaneras, en cuya descripción está contenido tanto la conducta punible como la sanción.

Resultaría excesivo realizar un panorama completo sobre el concepto de bien jurídico en materia penal, ya que la doctrina especializada ha sostenido diversas concepciones $)^{56}$. En el caso particular del derecho aduanero, la doctrina argentina ha expresado que el bien jurídico tutelado en las infracciones aduaneras es el control aduanero. Pero no el

\footnotetext{
${ }^{54}$ Valdés Costa, Instituciones ..., 36-62

${ }^{55}$ García Gómez, La simple negligencia ..., 25-28 (comentando las opiniones de Pérez Royo y Zornoza Pérez).

${ }^{56}$ Hans Welzel, Derecho Penal - Parte General- (Bs. As.: Roque Depalma Editor, 1956), 2; Mir Puig, Derecho Penal ..., 160-163
} 
control por el control mismo. Esto es, una función (el control) es solamente la acción y ejercicio de un empleo, facultad u oficio, y por ende para ser considerada bien jurídico debe ser completada con una finalidad específica, distinta del mero ejercicio funcional. Es por ello por lo que el control aduanero debe ser caracterizado como un bien jurídico intermedio, en tanto y en cuanto esa función fue otorgada a las aduanas para la salvaguarda de otros bienes jurídicos de distinta entidad que un formal buen desenvolvimiento de la función. Así, el control de la aduana se realiza sobre las importaciones y las exportaciones con la finalidad de preservar la correcta aplicación de las leyes que prescriben, en ocasión del tráfico de mercaderías: (i) restricciones a la importación o importación de carácter económico o no económico; (ii) la aplicación de tributos al ingreso y egreso de mercaderías; (iii) devoluciones de tributos a fin de facilitar su exportación. El control aduanero es entonces un medio (un bien jurídico instrumental) para preservar la correcta aplicación de las leyes que tutelan determinados bienes jurídicos que hacen a una determinada política de comercio exterior del Estado, y que tienen por objeto finalidades: económicas (v.g. protección de la producción), no económicas (seguridad pública, salud pública), fiscales (protección de la renta fiscal aduanera) o de incentivo a las exportaciones (devoluciones de tributos) ${ }^{57}$.

El concepto anterior sería trasladable al sistema infraccional de nuestro país, con -al menos- dos excepciones.

${ }^{57}$ Barreira y Vidal Albarracín, 934-936. Barreira ha reiterado luego este concepto en otros trabajos: "La relación jurídica tributaria y la relación jurídica aduanera", en Revista de Estudios Aduaneros del Instituto Argentino de Estudios Aduaneros, No. 18 Año XVIII (Primer Semestre de 2007): 55 y ss.; "Sistema y metodología del Código Aduanero Argentino", en la obra colectiva: Estudios de Derecho Aduanero (Homenaje a los 30 años del Código Aduanero), Juan Patricio Cotter -coordinador- (Bs. As.: AbeledoPerrot, 2011): 21-38, especialmente: 31-32. También y en sentido coincidente: Juan Patricio Cotter, Las infracciones aduaneras (Bs. As.: Abeledo Perrot, 2011), 73; Héctor G. Vidal Albarracín y Guillermo Vidal Albarracín, El Despachante de Aduana, (Bs. As.: Guía Práctica S.A. y Ediciones IARA S.A., 2016), 445-450; Héctor Vidal Albarracín, "El bien jurídico tutelado como medio eficaz de armonización internacional de los ilícitos aduaneros", en Revista de Estudios Aduaneros, Instituto Argentino de Estudios Aduaneros - Buenos Aires, No. 17 Año XVII (2005 - 2006): 33. 
La primera consiste en que no existe ninguna infracción aduanera en la que el bien jurídico tutelado sea la violación del control aduanero en cuanto refiere a las devoluciones de tributos a fin de facilitar la exportación de la mercadería ${ }^{58}$ (ver punto iii en párrafo precedente). Si bien es la DNA quien envía a la Dirección General Impositiva (DGI) el mensaje de liquidación de beneficios (devolución de tributos) una vez culminada la exportación, los tributos que se devuelven no son aduaneros. No existe ninguna infracción aduanera ${ }^{59}$ que penalice la violación de este régimen (la violación consistiría en cualquier acto, doloso o culposo, cuyo resultado sea la obtención de una devolución indebida de tributos). Ello, sin perjuicio de que una conducta de este tipo podría movilizar otro orden represivo (tributario o penal). La segunda excepción refiere a la infracción de contravención (art. 200 del CAROU), en la cual -en nuestro concepto- se estaría afectando directamente el bien jurídico intermedio: el control aduanero. Recordemos que la descripción típica comprende: "La violación de leyes, decretos, o reglamentos dictados por órganos competentes que establecen deberes formales respecto de procedimientos aduaneros (...)". Es tan genérica la descripción típica de esta infracción, que cualquier afectación de los bienes jurídicos "finales" podría ingresar en la misma. Es más, podría existir contravención sin afectar ninguno de los bienes jurídicos finales: la violación de una norma que establece deberes formales respecto de procedimientos aduaneros no necesariamente es una norma que establece un régimen tributario, restricciones económicas o no económicas a la importación o exportación, o que representa un incentivo a las exportaciones. La errónea indicación en los casilleros del DUA del quilaje, del país de origen, o aún la violación de una norma adjetiva o formal referente a la tramitación de una operación aduanera, por menor que sea su importancia, constituiría una contravención. De ahí que

\footnotetext{
${ }^{58}$ El régimen de devolución de tributos fue creado por la ley No. 16.492 de 2 de junio de 1994 (con la modificación introducida por el artículo 362 de la ley No. 19.149 de 24 de octubre de 2013) y reglamentado por los decretos Nos. 558/94 de 21 de diciembre de 1994 y 54/003 de 7 de febrero de 2003. El art. 8o. de este último decreto estableció que el Ministerio de Economía y Finanzas es el organismo encargado de expedir los certificados de crédito correspondientes a esta devolución de tributos. Esta atribución fue delegada posteriormente a la Dirección General Impositiva.

${ }^{59}$ Eventualmente, un comportamiento de este tipo podría caer en la contravención, cuya redacción es omnicomprensiva.
} 
todo parecería indicar que, en esta infracción, resulta violado el bien jurídico intermedio. Si la acción infraccional resulta violatoria de una regla de procedimiento aduanero, debe concluirse que lo que se afecta es el normal desenvolvimiento del control aduanero, el mero ejercicio de este, sin contemplar la consecuencia de esa vulneración. Siempre, claro está, que ese comportamiento no encaje en otra infracción aduanera.

En apoyo de esta tesis, puede recordarse que la tarea principal de la aduana radica en el control de la importación y exportación de las mercaderías como modo de ejecutar la política económica establecida por el Estado respecto del comercio exterior ${ }^{60}$. Basaldúa indica que el término "control" deriva de "contre-role", y "role" alude a una forma de identificación, anotación o registro que posibilita luego una comparación o confrontación, una verificación recíproca. Recuerda luego que en el Glosario de Términos Aduaneros Internacionales de la Organización Mundial de Aduanas (OMA) se define al "control aduanero" como "el conjunto de medidas adoptadas por la aduana con el fin de asegurar la aplicación de la legislación aduanera" ${ }^{61}$. El art. 6.1 del CAROU se refiere propiamente a la competencia de la DNA: la aplicación de la legislación aduanera, lo que coincide con la noción de control aduanero establecida en el Glosario de la OMA, según hemos visto.

El CAROU define la legislación aduanera como: "las disposiciones legales, sus normas reglamentarias y complementarias, así como las resoluciones de carácter general dictadas por la Dirección Nacional de Aduanas, en ejercicio de sus competencias legales, relativas a la importación y exportación de mercaderías, los destinos y las operaciones aduaneros" (art. 2o. "Definiciones básicas").

Por consiguiente, la violación de leyes, decretos, o reglamentos dictados por órganos competentes que establecen deberes formales respecto de procedimientos aduaneros (el tipo de la contravención), afecta al control aduanero, en tanto vulnera

${ }^{60}$ Barreira y Vidal Albarracín, La responsabilidad en las infracciones aduaneras, 928930. Ricardo Xavier Basaldúa, "La Aduana: concepto y funciones esenciales y contingentes", en Revista de Estudios Aduaneros. Instituto Argentino de Estudios Aduaneros, No. 18, Año XVIII (Primer Semestre de 2007): 41-42.

${ }^{61}$ Ricardo Xavier Basaldúa, "Los principios jurídicos del control aduanero modernizado en el tráfico transfronterizo contemporáneo", en El Derecho. Diario de Doctrina y Jurisprudencia-, Buenos Aires, martes 26 de noviembre de 2013, Año LI: 2. 
dicho control que consiste justamente en asegurar la aplicación de la legislación aduanera. Anotemos que el control aduanero se vería afectado por el incumplimiento de “deberes formales", como serían por ejemplo el incumplimiento por parte de un despachante de aduana de su obligación de archivo de la documentación (art. 26 del CAROU), o el incumplimiento de alguno de los deberes formales previstos en el artículo 70 del Código Tributario (aplicable a la materia aduanera -IMADUNI- en virtud de lo dispuesto por el art. 32 del decreto-ley No. 14.629). La violación de deberes sustanciales quedaría eventualmente abarcada por otra infracción aduanera ${ }^{62}$.

No sería esta una tesis aislada, en tanto autores que entienden que el control aduanero es un bien jurídico instrumental no dejan de destacar que la jurisprudencia argentina ha expresado que el control aduanero no está en función de otro bien jurídico sino de la sociedad, para lo cual es valioso que el Estado preste adecuadamente esa función de control o prestación sobre toda mercadería que ingrese o egrese al o del territorio aduanero. Ello con independencia de sus fines de percepción de tributos y cumplimiento de prohibiciones a la importación y a la exportación. No se tutela el mero ejercicio sino la normalidad de ese ejercicio castigando a quienes lo dificulten u obstaculicen (fallo de la Cámara en lo Penal Económico, sala III, en el caso "Medovsky" del 8/8/68. Misma sala voto del Dr. Landaburu, Reg-352/8. Fo. 246) ${ }^{63}$.

El concepto de bien jurídico elaborado por la doctrina argentina, sí parecería aplicable a las restantes infracciones aduaneras. En los casos de la diferencia (art. 201), de la defraudación común (art. 204), de la defraudación de valor (art. 205), del desvío de exoneraciones (art. 208) y del contrabando (art. 209), claramente existe una violación de aquellas normas de control que refieren a la aplicación de la legislación tributaria aduanera (el elemento "perjuicio de la renta fiscal" integra la estructura típica de estas infracciones). Y en el caso del contrabando por violación de requisitos esenciales para la importación o exportación definitivas de determinadas mercaderías que establezcan leyes y reglamentos especiales aún no aduaneros (art. 209 in fine del CAROU), se

62 Pablo Labandera, "La infracción administrativa de contravención aduanera. Su régimen jurídico a la luz del Derecho nacional”, en Revista Tributaria (Instituto Uruguayo de Estudios Tributarios), No. 236, Tomo XL (setiembre-octubre 2013): 837.

${ }^{63}$ Citado por Guillermo Vidal Albarracín, "El bien jurídico tutelado como medio eficaz de armonización internacional de los ilícitos aduaneros", 33, nota al pie No. 25. Publicado en Revista de Estudios Aduaneros No. 17, Año XVII (2005-2006). 
estaría violando el control aduanero relacionado con la aplicación de normas que establecen restricciones o prohibiciones de carácter económico o no económico a la exportación o importación.

\section{El tipo penal. Las referencias subjetivas}

Los elementos constitutivos de la figura no deben confundirse con los elementos constitutivos del delito, que son siempre los mismos: la antijuridicidad y la culpabilidad $^{64}$. Dentro de la pluralidad de elementos de la figura es posible trazar algunas distinciones.

En primer lugar, el verbo definitorio. Este es el nombre de la acción. Siendo que el delito no consiste en un hacer en general, sino en un hacer determinado, el verbo asumirá las más variadas formas: matar, apoderarse, ofender, entrar, fugarse, agredir, difamar, falsificar. Desde luego, en muchas figuras la acción está definida con más de una palabra, y aún es frecuente que el verbo empleado vaya acompañado de elementos que generalmente restringen su sentido originario.

A veces, además del verbo o de la frase verbal, las figuras contienen casi siempre elementos provenientes del mundo físico, humano y cultural, y mediante el juego de esos agregados la acción definida cobra o bien su verdadera fisonomía o bien una serie de características adicionales. Estaríamos así en presencia de los elementos objetivos del tipo ${ }^{65}$. Estos consisten entonces en una descripción de hechos, cosas, personas, relaciones, et., de naturaleza material objetiva, cuyo examen requiere una actividad mental comprobatoria de realidades externas, puramente cognoscitivas: se trata de los elementos objetivos del tipo ("matare a otro", daño en el cuerpo o en la salud", "defraudare a otro valiéndose de ardid o engaño", "llevar públicamente insignias o distintivos de un cargo que no se ejerce", una "riña", "padrinos", "armas", un lugar determinado, la clientela, una cosa, máquinas, vehículos, etc. ${ }^{66}$.

Por otro lado, la admisión de elementos síquicos o internos correspondientes al autor dio lugar a la teoría de los elementos subjetivos del tipo. Representa un elemento subjetivo del tipo todo elemento suyo que aluda a una situación anímica del autor del

\footnotetext{
${ }^{64}$ Soler, Derecho Penal ..., 149.

${ }^{65}$ Soler, Derecho Penal ..., 150.

${ }^{66}$ Ricardo C. Núñez, Manual de Derecho Penal, Parte General (4ª Edición actualizada, Marcos Lerner, Editora Córdoba, 1999), 139; Soler, Tomo II (Buenos Aires: Tipográfica Editora Argentina, 1973), 150.
} 
delito, cualquiera que sea su naturaleza. Puede ser un saber ("sabiendo que no lo son"), una intención ("proponiéndose", "para satisfacer", "fuere dirigido a", "con miras", "ánimo de lucro", “con el fin de procurar”), un motivo (causa o razón del hecho) ("por precio o promesa remuneratoria", "por placer, codicia", odio racial o religioso", "en virtud de una connivencia con el deudor o con un tercero", "con indudable motivación ideológica comunista"), un sentimiento ("maliciosamente") o un estado afectivo (“estado de emoción violenta") ${ }^{67}$. Estos elementos del tipo o figura, como todos los demás, son abarcados por la valoración objetiva por la cual se determina si la totalidad de esos datos constituye un hecho antijurídico ${ }^{68}$.

Roxin utiliza el concepto de "elementos descriptivos" del tipo (en cuyo concepto se comprenden tanto los elementos subjetivos y objetivos), que requieren una percepción sensorial. Reproducen determinados datos o proceso corporales o anímicos y son verificados de modo cognitivo por el Juez. En tanto que los elementos objetivos y los subjetivos del tipo están determinados descriptivamente (porque como se ha dicho refieren a comportamientos corporales o anímicos), los elementos normativos del tipo sólo pueden determinarse por una valoración que puede ser de distinta naturaleza ${ }^{69}$. Puede ser una valoración de índole jurídica que implique el juicio sobre la antijuridicidad del hecho ("contrarias a la ley", "ilegítimamente", "ilegalmente", "sin causa justificada", “injuria”, "ajeno"). Estos son los elementos normativos que significan el adelanto sistemático de la antijuridicidad del hecho al momento del examen de su tipicidad. Su existencia es incompatible con la concurrencia de causas de justificación. Otras veces la valoración típica es de índole jurídica, pero el juicio que demanda, aunque referido al derecho, no decide definitivamente sobre la antijuridicidad del hecho, sino sobre una determinada cuestión jurídica (“cosa mueble total o parcialmente ajena", "sin la debida autorización") ${ }^{70}$. De cualquier forma, se advierte que la valoración sobre estos elementos ya sea indicativa o no de la antijuridicidad, siempre es jurídica pues se trata de elementos que sin una definición jurídica previa carecen de toda realidad. El objeto mencionado no se trata de un hecho o una cosa de la naturaleza, sino un objeto cuya existencia depende de su validez jurídica. Los elementos que

\footnotetext{
${ }^{67}$ Núñez, Manual ..., 140-141. Soler, Derecho Penal..., Tomo II, 151.

${ }^{68}$ Soler, Derecho Penal..., Tomo II, 150-151.

${ }^{69}$ Roxin, Derecho Penal..., 305-306.

${ }^{70}$ Núñez, Manual..., 142.
} 
pueden ser calificados como específicamente normativos son aquellos que ontológicamente pertenecen al mundo del derecho. Cuando una figura menciona por ejemplo "una puerta" es casi seguro que se trate de lo mismo que es puerta para el carpintero o herrero. Cuando la ley se refiere en cambio a hipoteca, a cosa ajena, a documento, a posesión, a propiedad, a préstamo, el objeto mentado es una realidad pura y exclusivamente jurídica ${ }^{71}$.

Por dolo típico se entiende, según una usual fórmula abreviada, el conocimiento (saber; lo cual es un requisito intelectual) y voluntad (querer; lo cual es un elemento volitivo) de los elementos del tipo objetivo ${ }^{72}$. Saber y querer la realización del tipo, es el dolo típico, pero en ocasiones la ley requiere que, además concurran en el autor otros elementos subjetivos para la realización del tipo (las referencias o elementos subjetivos del tipo, como se expresó anteriormente). Así, en el delito de hurto, el tomar una cosa ajena mueble intencionalmente no da lugar todavía al tipo de hurto. Es preciso para ello que, además de conocer y querer tomar la cosa (dolo), el autor lo haga con "ánimo de lucro". Por ello, quien sustrae bienes a su deudor moroso para realizar su derecho con ellos, no comete el delito de hurto y resultará impune (por ausencia de tipicidad) salvo que emplee violencia, intimidación o fuerza en las cosas. Los elementos subjetivos del tipo (o del injusto) son todos aquellos requisitos de carácter subjetivo distintos al dolo que el tipo exige, además de éste, para su realización ${ }^{73}$.

Podría así existir (ver la infracción de contrabando - art. 209 del CAROU-) una acción consistente en el ingreso intencional de una mercadería al territorio aduanero sin la documentación correspondiente, pero a la vez sin las características de querer que ese ingreso "esté destinado" a producir una pérdida de renta fiscal o una violación de requisitos esenciales para la importación o exportación, etc. de determinadas mercaderías. En este caso podría sostenerse que falta un elemento subjetivo del tipo, y en consecuencia no existiría la infracción.

Esto nos lleva al examen de algunos tipos infraccionales aduaneros, a la luz de los conceptos expresados en los párrafos anteriores.

\footnotetext{
${ }^{71}$ Soler, Derecho Penal..., Tomo II, 151-152.

${ }^{72}$ Roxin, Derecho Penal..., 308; 415-416.

${ }^{73}$ Mir Puig, Derecho Penal..., 287.
} 


\section{Examen de algunos tipos en el Derecho Aduanero Sancionatorio}

\section{Sobre la forma de incriminación subjetiva en el CAROU}

El CAROU acoge, con relación a determinadas infracciones aduaneras, un sistema de incriminación abierta (numerus apertus) ${ }^{74}$ de la imprudencia, a través de la previsión de una cláusula general, que relacionada con varios artículos que definen tipos, permiten la punición general, tanto de la imprudencia (culpa) como del dolo. En efecto, el artículo 213 ("Responsabilidad") establece en su numeral 1: "Las infracciones aduaneras de defraudación, defraudación de valor, desvío de exoneraciones y contrabando se imputarán a título de dolo". No es éste el criterio más extendido en Derecho comparado penal. Suele considerarse más adecuada a los principios de legalidad y de ultima ratio del Derecho penal la técnica de incriminación limitada (numerus clausus) de un número determinado de delitos culposos que la ley prevea en cada caso tras las correspondientes figuras dolosas ${ }^{75}$.

En efecto, el tipo podría contener referencias subjetivas del injusto que harían inaplicable una imputación a título de simple culpa; además, el sistema de cláusulas generales confiere una extraordinaria amplitud a la punibilidad de la imprudencia, erigiéndola en regla general. Por ello el derecho penal ha optado por sustituir el sistema de incriminación general de la imprudencia por el sistema de tipificación cerrada y excepcional de la imprudencia ${ }^{76}$. En particular, nuestro Código Penal adoptó este último sistema al establecer en su artículo 19 que el hecho ultraintencional y el culpable sólo son punibles en los casos determinados por la ley.

Si bien el CAROU no ha seguido este último criterio, lo cierto es que el sistema subjetivo de incriminación abierta puede chocar con las dificultades anotadas anteriormente: la estructura del tipo puede revelar que en la infracción descripta existen elementos o referencias subjetivas, las que sólo son posibles en caso de que la infracción se castigue a título de dolo. Si ello sucediera -lo que será objeto de análisis

\footnotetext{
${ }^{74}$ Concepto tomado de Mir Puig, Derecho Penal..., 292.

${ }^{75}$ Mir Puig, Derecho Penal..., 292.

${ }^{76}$ Mir Puig, Derecho Penal..., 293
} 
más adelante- la norma de "incriminación abierta" perdería sentido o directamente no sería aplicable.

\section{El tipo de la contravención}

Ya Berro había indicado que la contravención -en referencia a la infracción tributaria, cuyo texto es muy similar al de la infracción aduanera- que la remisión a deberes impuestos por otras normas ajenas al artículo 95 del Código Tributario (en el caso de la contravención aduanera: ajenas al artículo 200 del CAROU) es una norma sancionatoria en blanco, que necesita la definición de esos deberes formales ${ }^{77}$. Como se dijo anteriormente, en este tipo de normas solamente queda fijada con exactitud invariable la sanción, pero no la materia punible, en relación con la cual la norma legal acude a otras normas. De esta manera, el blanco puede ser llenado por normas de rango inferior (en el caso del artículo 200 del CAROU, se hace referencia a "decretos o reglamentos"), que incluso pueden ser dictadas con posterioridad a la existencia de la figura infraccional.

Recordemos que en el derecho administrativo sancionador el contenido de una ley en blanco comprende los siguientes elementos: a) regulación sustantiva de la materia, que no pretende ser exhaustiva; b) determinación de instrucciones, criterios o bases que resultan suficientemente expresivos como para que, a partir de ellos, pueda luego desarrollarse la normativa; c) una habilitación reglamentaria para que el Reglamento regule la materia penetrando en una zona reservada a la ley, sin exceder las instrucciones legales; d) una remisión al resultado de la colaboración reglamentaria que, en los términos dichos, se ha posibilitado u ordenado ${ }^{78}$.

Corresponderá en el futuro a la doctrina y a la jurisprudencia determinar en qué medida se dan estos elementos, y si la contravención, tal como está redactada, infringe o no el principio de legalidad ${ }^{79}$.

\section{El tipo de la diferencia}

\footnotetext{
${ }^{77}$ Federico Berro. Los ilícitos tributarios y sus sanciones, 61. Concepto retomado por Pablo Labandera, "La infracción administrativa de contravención aduanera. Su régimen jurídico a la luz del derecho nacional”, en Revista Tributaria Instituto Uruguayo de Estudios Tributarios, No. 236, Tomo XL (Setiembre - Octubre 2013): 837.

${ }^{78}$ Nieto, Derecho Administrativo ..., 227-228.

${ }^{79}$ Para un mayor desarrollo sobre todos los aspectos de la contravención, ver el trabajo ya citado de Labandera, en Revista Tributaria, 833-854. Hacemos notar que el referido trabajo fue escrito antes de la vigencia del CAROU.
} 
Se trata de una infracción genérica que tiene varios tipos. En relación con la diferencia de clasificación o especie (art. 210, numeral 1 de los literales A y B del CAROU), estaríamos en presencia de un tipo abierto. En efecto, para establecer el tipo de la prohibición, el Juez deberá proceder a una interpretación sobre si en el caso concreto existió una diferencia en la clasificación arancelaria del producto, o si el origen está bien otorgado. En relación con la diferencia de "más peso, mayor cantidad" u "otras mercaderías, además de las declaradas" (art. 210, numerales 2 y 3 del literal A y numeral 2 del literal B del CAROU), estaríamos en presencia de un tipo cerrado. En efecto, la materia de la prohibición está descripta en forma que no requiere del intérprete un juicio positivo para determinar la antijuridicidad.

A diferencia de la materia penal, no están previstas causas de justificación. Asimismo, la norma del artículo 213.3 del CAROU parecería vedar -en principio- toda investigación sobre la existencia de la falta de culpa. El examen sobre la posible extensión de causas de justificación similares a las del orden penal, o el examen de si la norma citada del CAROU establece o no una responsabilidad de tipo objetivo, exceden el ámbito de este trabajo.

\section{El tipo de la defraudación}

Podría caber la duda de si la defraudación común (art. 204 del CAROU) constituye un tipo en blanco dado que el verbo típico refiere genéricamente a "violación de leyes, decretos o reglamentos", de tal forma que el precepto podría considerarse indeterminado y debería ser complementado por una disposición posterior que le dé sentido, actualidad y concreción. No obstante, el tipo no se agota en la mera violación de leyes, etc. por acción u omisión, sino que el "perjuicio al Fisco" parece ser (i) o una referencia subjetiva del tipo, consistente en una determinada intención, motivación o impulso: provocar un perjuicio al Fisco en la percepción de la renta fiscal o en la concesión de incentivos o beneficios económicos o tributarios; (ii) o una referencia a un resultado determinado (pérdida de renta fiscal, etc.) sin el cual no puede existir la infracción.

Entonces, la antijuridicidad de la acción en la defraudación común no estaría indeterminada, no debiéndose recurrir a normas complementarias como en los delitos en blanco. Ello, en la medida en que es posible para el Juez tipificar el ilícito, examinando si la acción típica está teñida por la motivación o impulso ya señalado o, alternativamente, si produce un determinado resultado dañoso.

Ello arroja también que la defraudación común parece subdividirse en dos tipos o infracciones diferentes. En un caso, la violación de las leyes, etc. "se traduce" en un 
perjuicio a la renta fiscal, con lo cual estaríamos frente a una infracción que exige un resultado, o sea una infracción de daño. En el otro caso, la violación, etc. "puede traducirse si pasase inadvertida" en el referido perjuicio. Esto significa que de algún modo el iter criminis está cortado, no se produce el resultado, pero igualmente se castiga el mero hecho de violar las leyes, etc., con lo cual estamos claramente ante una infracción de peligro.

En este último caso, hasta se podría considerar que la expresión "pudiera traducirse si pasase inadvertida, en un perjuicio al Fisco...", etc. constituye una referencia subjetiva del tipo. Como ya lo vimos ${ }^{80}$, estas referencias subjetivas son diferentes al dolo, pero lo acompañan y cumplen una función constitutiva del tipo penal, como el ánimo de lucro en el delito de hurto. Vienen a precisar el tipo penal, a dar cumplimiento al principio de certeza. Su inclusión dentro del tipo tiende a excluir la vaguedad y constituye un obstáculo a la arbitrariedad ${ }^{81}$.

Claro está que ello también nos llevaría a un tema anunciado ya más arriba en nuestra exposición: los elementos subjetivos del tipo sólo pueden existir en los delitos dolosos (ya que "acompañan" o "colorean” al dolo); con lo cual, más allá de la norma genérica del artículo 213 del CAROU, la figura típica de la defraudación común, en su variante de infracción de peligro, sería dolosa. Las referencias subjetivas anticipan la barrera de la protección penal, otorgando disvalor al acto por sobre el disvalor del resultado $^{82}$. El tipo queda consumado por la acción, no importando que se cumpla el hecho que el sujeto tiene en mira luego de dicha acción ${ }^{83}$.

\section{4.- El tipo de la defraudación de valor}

Esta infracción se configura cuando existe una declaración aduanera "que distorsione el valor en aduana de las mercaderías en perjuicio de la renta fiscal" (art. 205 del CAROU). Se trata de un tipo abierto, ya que la decisión sobre su configuración va a depender de un juicio positivo del juez para determinar la antijuridicidad.

${ }^{80}$ Supra.

${ }^{81}$ Diego Camaño Viera, "El delito de abuso de funciones en la nueva jurisprudencia de la Suprema Corte de Justicia”, Revista de Derecho Penal No. 17 (Segunda época Abril 2008 - FCU): 162. El autor cita al respecto a Bustos y Hormazábal.

${ }^{82}$ Camaño Viera, "El delito de abuso...: 162 (citando a Polaino).

${ }^{83}$ Camaño Viera, "El delito de abuso ...: 163. 
Conforme al Diccionario de la lengua española (22ava. Edición), "distorsionar" significa “causar distorsión”. Y a su vez, por “distorsión” (tercera acepción) se entiende: "Acción de torcer o desequilibrar la disposición de figuras en general o de elementos artísticos, o de presentar o interpretar hechos, intenciones, etc., deformándolos de modo intencionado" (el destacado no está en el original).

La declaración aduanera tiene un doble carácter (ver art. $1^{\circ}$ del decreto No. 312/98 de 3 de noviembre de 1998): se realiza y se solicita. Lo que puede "realizarse" es la declaración aduanera; lo que se "solicita" es la inclusión en un régimen aduanero de importación, exportación o tránsito, o sea -más genéricamente- un destino aduanero.

Barreira $^{84}$ indica que la declaración aduanera: (i) por una parte hace referencia al acto mediante el cual el interesado indica a la Aduana el régimen aduanero que desea aplicar a la mercadería; (ii) por otra parte indica el acto mediante el cual el mismo interesado comunica a la Aduana los datos exigidos por ésta para aplicar dicho régimen aduanero. La primera, más que una declaración, es una solicitud en donde se pide algo concreto, y no nos hallamos ante una declaración verdadera o falsa. La segunda, sería una "declaración informativa" en la cual el administrado nada pide, sino que se limita a informar sobre los datos de la mercadería y sobre los aspectos de la relación jurídica y comercial con su contraparte, con el fin de que el servicio aduanero pueda fiscalizar la correcta clasificación y valoración aduanera. Esta función informativa es susceptible -a diferencia de la primera- de ser verdadera o falsa.

El CAROU finalmente, también contempla estos dos aspectos de la declaración. El art. 65.1 se refiere a que la solicitud de inclusión de la mercadería en un régimen aduanero deberá formalizarse ante la Dirección Nacional de Aduanas mediante una declaración de mercadería. Luego, el art. 65.3 establece que la declaración debe contener los datos y elementos necesarios para permitir a la Dirección Nacional de Aduanas el control de la correcta clasificación arancelaria, la valoración de la mercadería y la liquidación de los tributos correspondientes, de acuerdo con lo previsto en la legislación aduanera.

84 Enrique C. Barreira, "La solicitud de destinación aduanera y la declaración aduanera", Revista de Estudios Aduaneros, Instituto Argentino de Estudios Aduaneros No. 14, Año XI (1er. y 2. Semestres de 2000 - 1er. Semestre de 2001): 115 y sgts. Barreira había tratado este tema con anterioridad en Código Aduanero. Comentarios. Antecedentes. Concordancias", T. II-A (Bs. As.: Abeledo Perrot, 1986), 200-201. 
Entonces, siguiendo la norma del art. 205 del CAROU, la declaración aduanera en su faz de "declaración informativa" puede "distorsionar" el valor en aduana. Siguiendo la definición del verbo "distorsionar" que se ha reproducido más arriba, la declaración informativa que "distorsiona" supone que el declarante presenta hechos, etc. "deformándolos de modo intencionado", porque de otra manera no podría conjugarse el verbo distorsionar. O, dicho de otra manera, en la declaración se presentan intencionadamente datos erróneos o inexactos que impiden la correcta valoración de la mercadería por parte de la Aduana, o sea datos que en definitiva distorsionan el valor en aduana.

La exacta descripción del verbo típico puede ser dificultosa, pero en definitiva carece de importancia. Podrá ser "declarar" o "distorsionar", "declarar en forma distorsionada", "distorsionar el valor en aduana en ocasión de la declaración aduanera", "efectuar una declaración aduanera en la cual se informe de manera distorsionada el valor en aduana"; etc., pero en todo caso siempre será una conducta intencional, ya que la expresión "distorsión" denota una intención. Por lo que, nuevamente, más allá de la norma genérica del artículo 213 del CAROU, el tipo infraccional de la defraudación de valor sería doloso, y por consiguiente no admitiría su imputación a título de culpa. En adición a ello también podría considerarse que se está en presencia de una referencia subjetiva del tipo que se agrega al dolo (el dolo consistiría en tener la conciencia y voluntad de distorsionar el valor en aduana); esta referencia consiste en el ánimo especial que mueve al declarante a tener conciencia y voluntad de la distorsión del valor en aduana, esto es provocar un perjuicio a la renta fiscal. Y como vimos, los elementos subjetivos del tipo sólo pueden existir en una infracción dolosa, por estar vinculados sin formar parte- al dolo. En cuyo caso, además, la efectiva causación de un perjuicio no sería exigida como requisito constitutivo de la infracción de defraudación de valor, que adquiriría así, la fisonomía de una infracción de peligro.

\section{El tipo del contrabando}

Nuevamente estamos en presencia de un tipo abierto. Pero es importante resaltar que en este caso, quizás todavía con mayor claridad que en el caso de la defraudación de valor, nos encontramos con una figura típica cuya configuración requiere dolo y con una referencia subjetiva del tipo.

En efecto, el verbo típico es "toda acción que tenga por objeto la entrada o salida de mercadería del territorio aduanero en forma clandestina o violenta $o$ documentación correspondiente". Y luego, aparece una clara referencia subjetiva del 
tipo: "que esté destinada a traducirse en una pérdida de renta fiscal o en la violación de requisitos esenciales (...)" (el destacado no está en el original). Una vez más debemos recordar que estas referencias son tendencias subjetivas que reflejan una expresión síquica del agente que tiende de modo especial a un determinado fin. Son distintos del dolo y reflejan intenciones que van más allá de querer que se realice el tipo o son disposiciones particulares internas que se ponen de manifiesto en el modo de obtener la realización del tipo ${ }^{85}$. El dolo en la infracción de contrabando consiste en la conciencia y voluntad de ingresar o extraer mercadería del territorio aduanero en forma clandestina, violenta o sin la documentación correspondiente. Esa acción (dolosa) está teñida en el tipo por una particular tendencia subjetiva (provocar una pérdida de renta fiscal o violar requisitos esenciales, etc.) que no puede ser otra cosa que indicativa, además, de la voluntad de realizar el tipo, debiéndose descartar en estos casos que la infracción o delito pueda castigarse simplemente a título de culpa o negligencia.

Nuevamente, la incriminación abierta prevista en el art. 213 del CAROU debe ceder ante la estructura del tipo del art. 209, la cual denota que la infracción de contrabando sólo puede castigarse a título de dolo.

\section{La culpa en el derecho sancionatorio}

\section{El concepto de culpabilidad (en el grado de negligencia o imprudencia)}

No existe en el Derecho Tributario Sancionador o, en general, en el Derecho administrativo una definición legal de la imprudencia o negligencia como en el derecho civil, ni tampoco doctrina y jurisprudencia han conseguido todavía perfilar el régimen técnico-jurídico de esta figura al nivel que lo ha hecho la dogmática penal ${ }^{86}$.

El contenido de la culpabilidad queda reducido al análisis fundamentalmente de tres aspectos: la imputabilidad, el conocimiento de la antijuridicidad y la exigencia de un comportamiento distinto ${ }^{87}$. Esto último nos lleva a la concepción normativa de la culpa.

\footnotetext{
${ }^{85}$ Milton Hugo Cairoli Martínez, El Derecho Penal Uruguayo y las nuevas tendencias penales. Tomo I -La Ley - El Delito- (Montevideo, FCU, 2000), No. 150, 180-181.

${ }^{86}$ García Gómez, "La simple negligencia ...: 73.

${ }^{87}$ López López, "El principio de culpabilidad ...: 266.
} 
Se consideraba a la culpabilidad como la relación subjetiva del sujeto con el resultado (concepto psicológico), pero en las primeras décadas del siglo XX este concepto fue reemplazado por el concepto normativo de culpabilidad, todavía hoy dominante. Junto a la "norma jurídica" que exigía una conducta externa y cuya infracción fundamentaría la antijuridicidad, existiría "implícitamente" una "norma de deber" que impondría a cada cual disponer su conducta interna del modo necesario para que se pueda corresponder con las exigencias impuestas por el ordenamiento jurídico a su conducta externa. En el concepto normativo se expresa la idea de que en la categoría del delito que sigue al injusto se trata de una valoración del acontecer del hecho de otro tipo en comparación con la contrariedad a deber y no sólo de un puro estado de cosas psíquico.

El concepto normativo de culpabilidad sólo afirma que una conducta culpable ha de ser "reprochable", aunque no responde la cuestión relativa a cuáles son los presupuestos materiales de los cuales depende la reprochabilidad. Se trata de la cuestión del concepto material de culpabilidad. La misma se contesta de manera diversa incluso por los defensores de un concepto normativo de culpabilidad. Para Roxin hay que entender la culpabilidad como actuación injusta pese a la existencia de asequibilidad normativa. Con ello se quiere decir que hay que afirmar la culpabilidad de un sujeto cuando el mismo estaba disponible en el momento del hecho para la llamada de la norma según su estado mental y anímico, cuando (aún) le eran psíquicamente asequibles "posibilidades de decisión por una conducta orientada conforme a la norma", cuando la posibilidad (ya sea libre, ya sea determinada) psíquica de control que existe en el adulto sano en la mayoría de las situaciones existía en el caso concreto ${ }^{88}$. En definitiva y más allá del concepto material de culpabilidad, debe retenerse que la concepción normativa de la culpa considera a ésta como un juicio de reproche por la realización del hecho antijurídico, cuando era exigible actuar conforme a derecho. Esto es el sujeto no sólo infringe la norma contenida en el tipo penal, sino que tal conducta le es reprochable porque actúa sin cumplir el deber de advertir el peligro ${ }^{89}$.

En el mismo sentido, y en nuestro derecho, Bayardo criticó la concepción psicológica de la culpa, al indicar que no se trata de un concepto psicológico puro, sino que también importa la violación de un deber jurídico: el de observar normas de precaución o de prudencia para no lesionar el derecho ajeno. El elemento psicológico radica en la

${ }^{88}$ Roxin, Derecho Penal..., 794-807.

${ }^{89}$ Mir Puig, Derecho Penal..., 537. 
omisión del agente de tener despierta la voluntad que posee de observar deberes de precaución y cautela que tiene todo súbdito del orden jurídico, causante de un resultado antijurídico. Al omitir, diverge, voluntariamente, su atención a otros momentos o actos. Según Mezger se habla de la culpa en un "momento anterior", en que en verdad, el sujeto quiso ${ }^{90}$.

No basta con la previsibilidad, puesto que además es necesario la infracción de la norma o el deber de cuidado, puesto que si el sujeto se atiene a la diligencia exigida y sin embargo produce el resultado típico su conducta no podrá calificarse de imprudente ${ }^{91}$. La culpa tiene pues un aspecto normativo representado por la inobservancia del cuidado objetivamente debido, que condiciona la antijuridicidad del hecho culposo y un aspecto subjetivo o individual que atiende a la capacidad personal del autor para observar el cuidado objetivamente debido y que se incluye en la culpabilidad ${ }^{92}$.

En el mismo sentido, Gamarra, al estudiar el concepto de "culpa" en sede de responsabilidad extracontractual, indica que todo individuo que vive en sociedad tiene el deber de actuar adoptando el cuidado o la prudencia que emplearía un buen padre de familia para prevenir el daño (art. 1324 C. Civil, inciso final). Por consiguiente, la diligencia media (de un buen padre de familia) es exigida con el objeto de evitar que el comportamiento negligente, imprudente, o desatento, pueda llegar a causar perjuicio a los otros sujetos. Justamente el evento dañoso se produce porque el sujeto incumplió su deber (normativo) de observar la debida diligencia, produciendo dicho evento dañoso que podía haber evitado con un mayor esfuerzo de atención"93.

\section{Los grados de la culpa}

La doctrina civil distingue entre culpa lata o grave, culpa leve y culpa levísima. La primera supone una falta grave de diligencia en cuanto no se ha puesto el cuidado que cualquier persona observaría (tradicionalmente se equiparaba con el dolo), o sea, es aquella culpa que es grosera o inexcusable ${ }^{94}$. La imprudencia grave es aquel cuidado o

${ }^{90}$ Fernando Bayardo Bengoa, Derecho Penal Uruguayo, Tomo II (2 $2^{\text {a }}$ Edición, JVS, Montevideo, 1968), 100, 105-106.

${ }^{91}$ García Gómez, “La simple negligencia ...: 69-70.

92 García Gómez, "La simple negligencia .... 70-71.

${ }^{93}$ Jorge Gamarra, Tratado de Derecho Civil Uruguayo, Tomo XIX, Tercera Parte, Responsabilidad Civil Extracontractual - Volumen 1º-, (Montevideo 1981), 97-106.

${ }^{94}$ Gamarra, Tratado..., 129. García Gómez, "La simple negligencia ...:78. 
diligencia, aquella atención que puede exigirse al menos cuidadoso, atento o diligente. Es decir, cuando el sujeto omite las más elementales medidas de cuidado o atención ${ }^{95}$. La culpa leve equivale a la diligencia normal o media -la del buen padre de familia-. En el derecho moderno, el límite de la responsabilidad es la llamada culpa leve (o culpa media); en efecto, el concepto de culpa está ligado indisolublemente a la diligencia del buen padre de familia, lo cual determina la exclusión de la categoría de la culpa levísima Es más adecuado el modelo medio, ya que todos los hombres (o la mayoría de ellos) está en condiciones de observarlo; en cambio el del hombre excepcional (que no incurre en culpa leve) puede obstaculizar excesivamente el libre desarrollo de la actividad humana ${ }^{96}$. El segundo grado lo constituye la imprudencia leve o simple, que supone la infracción de normas de cuidado no tan elementales como las vulneradas por la imprudencia grave. Se trata de normas que respetaría no ya el ciudadano menos diligente, sino uno cuidadoso. Se define por referencia al cuidado exigible al hombre medio $^{97}$.

Gamarra proclama la unidad de la culpa civil y penal, existiendo "razones decisivas" para ello. En ambos sistemas la culpa es la violación de una regla de comportamiento que se concreta en un deber de diligencia. Si culpa es no obrar con la diligencia de un buen padre de familia (art. 1344 C. Civil), el imprudente, imperito o negligente (art. 18 del C. Penal) es culpable. También lo es de acuerdo con la interpretación ya formulada, el que viola leyes o reglamentos. Todo el concepto podría compendiarse en la ida de negligencia 98 . "No se es culpable porque se ha querido, sino porque se ha querido lo que no se debía querer" dice Gamarra citando a Musotto ${ }^{99}$.

Y la culpa levísima significa la omisión de cuidado que pondrían las personas especialmente escrupulosas ${ }^{100}$. La imprudencia levísima significa un descuido ligerísimo o un pequeño incumplimiento de un aspecto marginal de la norma de cuidado $^{101}$. En este grado de la culpa, la diligencia exigida sería superior a la normal o

\footnotetext{
${ }^{95}$ López López, "El principio de culpabilidad ...: 228-229.

${ }^{96}$ Gamarra, Tratado ..., 128; García Gómez, "La simple negligencia ...:78.

${ }^{97}$ López López, "El principio de culpabilidad ...: 228-229

${ }^{98}$ Gamarra, Tratado ..., 130.

${ }^{99}$ Gamarra, Tratado ..., 133.

${ }^{100}$ García Gómez, "La simple negligencia ...:78

${ }^{101}$ García Gómez, "La simple negligencia ...:79
} 
media, del buen padre de familia, tomándose por modelo al hombre diligentísimo, o muy prudente y diligente, dotadísimo, un excelente pater familias. Vale decir, que se responde por los descuidos de importancia mínima, casi imperceptibles, perdonables ${ }^{102}$. Consiste en la infracción de la diligencia que observaría una persona excepcionalmente cuidadosa y concienzuda. Se trata de pequeñas faltas de atención que no son siempre evitables ni siquiera para una persona concienzuda o escrupulosa. Esta última no es sancionada en el ámbito penal ${ }^{103}$.

¿Es razonable sancionar una conducta en la que la persona sólo ha incurrido en culpa levísima?

La consecuencia de sancionar conductas con cualquier grado de negligencia, como lo hace la Ley General Tributaria de España (art. 183.1), ha merecido críticas, Esto implicaría -dice la doctrina de ese país- juzgar con el modelo del "hombre perfecto", o extraordinariamente meticuloso, porque si se parte de que hay responsabilidad por culpa levísima, el modelo de diligencia es el del hombre perfecto o sumamente meticuloso, como es lógico. Por todo ello parece que la recta interpretación del artículo impide sancionar todos los supuestos en los que la negligencia apreciable es la mínima ${ }^{104}$. Las exigencias del principio de culpabilidad, y específicamente de una de sus derivaciones, la proporcionalidad adecuada entre la gravedad del hecho cometido y la respuesta sancionadora, el marco actual de proliferación de deberes y obligaciones tributarias sobre los contribuyentes, cuyo cumplimiento no está exento de dificultades, implica necesariamente considerar la diligencia media, la del ciudadano prudente, como criterio que salvaguarda cualquier reproche sancionador. Ello supone considerar impunes las pequeñas ligerezas o descuidos que sólo un experto podría haber evitado ${ }^{105}$. Sólo serían constitutivas de infracción las acciones u omisiones tipificadas en las normas en las que, al menos, no se haya puesto la diligencia media. Así, en la Sentencia de la Audiencia Nacional de 8 de marzo de 1994 se indica:

102 Gamarra, Tratado..., 127.

${ }^{103}$ López López, "El principio de culpabilidad ...: 228-229

${ }^{104}$ López López, “El principio de culpabilidad ...: 235-239.

105 García Gómez, "La simple negligencia ...: 80. López López señala que la LGT enumera en su artículo 178 una serie de principios entre los cuales menciona el de proporcionalidad. En su opinión, no sería necesaria esta previsión expresa, puesto que este principio se halla implícito en la noción misma de Estado de Derecho (260). 
(...) una dudosa omisión de diligencia que sólo adoptarían los hombres muy cuidadosos y que integraría la culpa levísima del Derecho romano, debe quedar al margen de la sanción"106: "la complitud y veracidad de la declaración junto con la razonabilidad de la interpretación son dos elementos que han de concurrir simultáneamente para excluir la culpabilidad"107.

En la medida en que, en nuestro derecho represivo aduanero, cuatro infracciones pueden ser sancionadas a título de dolo o culpa, resulta, al menos en cuanto a las mismas, imposible prescindir del elemento subjetivo. En términos generales, ya la doctrina que estudia el derecho administrativo sancionador en nuestro país había afirmado que no existe responsabilidad sin culpa (aunque sin pronunciarse sobre el grado exigible de culpa para configurar la responsabilidad) ${ }^{108}$.

Entendemos en base a todo lo expuesto, que el concepto de "culpa" en el CAROU debería entenderse en el sentido en que lo hace la doctrina civil y tributaria, esto es como culpa leve, excluyendo la culpa levísima.

\section{Trascendencia del error en materia penal y aduanera}

En materia penal, el error es una de las causas de inculpabilidad. Dice Bayardo:

El inculpable es completamente capaz, y si a la postre no se le responsabiliza por su conducta, es porque incurrió en un error, ya que consideramos que en solución de estricto formalismo, en la base misma de la exclusión de la culpabilidad no hay otra cosa que un error, a mérito del cual el agente actúa sin tener conciencia del disvalor de su conducta, que en definitiva es lo que suministra el contenido mismo de la culpabilidad ${ }^{109}$.

Así como la ignorancia es la ausencia de toda noción relativa a un objeto, el error es una falsa noción referente a un objeto; dicho de otra manera, en tanto que la ignorancia tiene un carácter negativo e implica un puro no saber, el error es un quid positivo que importa cierto convencimiento implicando la presencia de nociones falsas, equivocadas

106 García Gómez, “La simple negligencia...: 81.

${ }^{107}$ García Gómez, "La simple negligencia...: 98, citando a Pérez Berengena.

${ }^{108}$ Lorenzo de Viega Jaime, Sanciones administrativas, 83. Ver asimismo sentencias del Tribunal de lo Contencioso Administrativos Nos.749 de 31 de julio de 1996 y 714 de 24 de noviembre de 2004, ambas citadas en Delpiazzo y Ruocco, Tratado Jurisprudencial y doctrinario, Tomo I, 153.

${ }^{109}$ Bayardo Bengoa, Derecho Penal ..., Tomo II, 145. 
o disparatadas, es decir, un saber mal ${ }^{110}$. Aunque la diferenciación carece de todo interés práctico, al punto que la doctrina y la legislación comparada suelen equiparar los efectos jurídicos del error y la ignorancia ${ }^{111}$.

En la doctrina española se ha dicho que en materia tributaria existe una ausencia de regulación legal que plantea la duda en torno a la virtualidad del error como circunstancia determinante de la atipicidad de la conducta (en concepto enteramente trasladable al derecho sancionatorio aduanero). Pero -afirma la doctrina- a pesar de no reconocerse esta circunstancia en el derecho sancionador tributario de dicho país, no es posible negar su aplicación con carácter general en el administrativo sancionador, pues ello se deriva de la propia exigencia de dolo o culpa en la infracción y su consideración a efectos de la calificación de la conducta infractora ${ }^{112}$. La relevancia del error, la admisión de dicha circunstancia es una consecuencia directa del carácter subjetivo de la infracción tributaria ${ }^{113}$. El tribunal Constitucional de España destaca el hecho de que, aunque no se recoja entre las causas de exención de responsabilidad la del error, afirmado el carácter subjetivo de la responsabilidad, no es necesario que se haga constar expresamente. Si se aceptara la responsabilidad objetiva en las infracciones administrativas la consecuencia inmediata sería la irrelevancia del error ${ }^{114}$.

Los desarrollos anteriores nos hacen concluir que la imputación a título de responsabilidad subjetiva que efectúa el CAROU en varias infracciones, determina inexorablemente la consideración del error como circunstancia susceptible de eliminar la culpa. Destaquemos finalmente que nuestro Código Tributario, al enumerar los eximentes de responsabilidad de las infracciones tributarias, incluye expresamente: "El error excusable en cuanto al hecho que constituye la infracción” (art. 106, numeral $\left.3^{\circ}\right)^{115}$.

\footnotetext{
${ }^{110}$ Bayardo Bengoa, Derecho Penal ..., Tomo II, 146.

${ }^{111}$ Bayardo Bengoa, Derecho Penal ..., Tomo II, 147.

${ }^{112}$ López López, "El principio de culpabilidad ...: 254.

${ }^{113}$ López López, “El principio de culpabilidad ...: 281.

${ }^{114}$ López López, "El principio de culpabilidad ...: 255.

${ }^{115}$ Sobre el error en materia tributaria ver: José Luis Shaw, "El error como eximente de responsabilidad en materia de infracciones tributarias", en Revista Tributaria, Instituto Uruguayo de Estudios Tributarios, No. 47, Tomo IX (1982): 111 y sgts.; Sol Agostino y
} 


\section{Error: inculpable, esencial y decisivo}

El error vencible es aquél que hubiese podido evitarse si se hubiera observado el debido cuidado, por lo que puede considerarse error "imprudente". Error invencible es, por el contrario, el que no hubiese logrado evitarse ni aun aplicando la diligencia debida (error "no imprudente"). Así, el error vencible excluirá el dolo, pero no la imprudencia, por lo que procederá, de ser punible ésta en el delito de que se trate, la estimación de la modalidad de imprudencia correspondiente. El error invencible excluirá tanto el dolo como la imprudencia, por lo que en principio dará lugar a la impunidad ${ }^{116}$.

Para determinar si la conducta puede ser imputada a su autor a título imprudente, habrá de estarse a las posibilidades que éste tenía de vencer su error. De manera que la vencibilidad o la imprudencia, resultan del hecho de que el sujeto disponía -o debía disponer- de los elementos para haber salido de su situación de error si hubiera aplicado la diligencia debida. Lo cual nos reenvía al análisis del estudio de la infracción del deber objetivo de cuidado expresada ahora en la no evitación del referido error evitable o vencible, todo lo cual habrá de ponderarse según las circunstancias del hecho concreto y las personales del autor ${ }^{117}$.

\section{Error de hecho y error de derecho}

Bayardo indica acertadamente que en nuestro derecho la causa de inculpabilidad se restringe al error de hecho (art. 22 del Código Penal), puesto que el error de derecho (el que emana de la ignorancia de la ley -art. 24 del Código Penal) elimina el dolo, pero deja subsistente la culpa ${ }^{118}$. Así, la presunción del art. 24 del Código Penal (el error de derecho se presumirá voluntario sin admitirse prueba en contrario), parecería desterrar toda defensa basada en un error de derecho invencible, el que por lo contrario es aceptado en otras legislaciones. Y demás está decir que la consecuencia anotada sólo rige en el ámbito penal, y no en otras ramas del derecho sancionatorio de nuestro país.

Se tiene error de hecho en toda hipótesis de verificación de un evento objetivamente conforme a la hipótesis típica prevista por la ley, cuando empero, el agente se ha formado un falso juicio sobre una situación de hecho esencial para la estructura del

Natalia Acosta Casco, "Las eximentes de responsabilidad en materia de infracciones tributarias" en Revista Tributaria No. 248, Tomo LXII (2015): 717 y sgts.

${ }^{116}$ Mir Puig, Derecho Penal..., 279-280.

${ }^{117}$ López López, "El principio de culpabilidad ...: 257.

${ }^{118}$ Bayardo Bengoa, Derecho Penal..., Tomo II, 148 y ss. 
delito; es decir una falsa representación de por lo menos uno de aquellos elementos objetivos que son esenciales en la estructura de la figura delictiva, descripta en un modelo legal, siempre que existan como elementos constitutivos suyos, con cuya concurrencia existe la figura y se diferencia de otros delitos. Y si es indispensable para que exista el dolo, el conocimiento de los aludidos elementos, es muy obvio que el error que recayera sobre alguno de los mismos, en principio, excluye el dolo mismo ${ }^{119}$.

\section{Error de tipo y error de prohibición}

En la doctrina penal contemporánea se ha abierto paso una clasificación diferente del error: el error de tipo y el error de prohibición.

En el caso del error de tipo hay una falta de conocimiento y por tanto quien actúa no ha incluido en absoluto en su representación un elemento del tipo. Así pues, quien por ejemplo no se da cuenta de que el supuesto espantapájaros sobre el que dispara es una persona no actúa con dolo; el error de tipo no supone ninguna falsa suposición, sino que basta con la falta de la correcta representación; así, tampoco existe dolo en el caso de quien seduce a una muchacha suponiendo erróneamente que la misma ha superado el límite de protección para configurar la violación, sino también incluso cuando no ha realizado reflexión de clase alguna sobre la edad de la muchacha; pues tampoco en este caso conoce una circunstancia que pertenece al tipo legal (o sea la circunstancia de que la muchacha aún no tiene dieciséis años); o también quien se apodera de una cosa ajena, creyéndola propia, no incurre en el delito de hurto.

El caso del error de prohibición (asimilable al error de derecho), es el caso de quien mantiene relaciones sexuales con una mujer enferma mental y no sabe en absoluto que ello está prohibido. Hay que tener en cuenta que existe un error de prohibición no sólo cuando el sujeto se representa positivamente que no actúa de modo antijurídico, sino ya cuando le falta la conciencia de la antijuridicidad sin que hubiera reflexionado nunca sobre tal posibilidad ${ }^{120}$. Cuando el sujeto desconoce la ilicitud de su conducta incurre en el denominado error de prohibición ${ }^{121}$.

Si el tipo comisivo infractor es imprudente, la consecuencia es que el error excluye el dolo, pero no necesariamente la imprudencia, de manera tal que esta última podrá ser

\footnotetext{
${ }^{119}$ Bayardo Bengoa, Derecho Penal..., Tomo II, 153-154.

${ }^{120}$ Roxin, Derecho Penal..., 871.

${ }^{121}$ López López, "El principio de culpabilidad ...: 253.
} 
sancionada incluso con la concurrencia de error de tipo ${ }^{122}$. Ambos tipos de errores excluyen el dolo, pero si fueren vencibles, no excluyen la culpa.

Se ha dicho que los dos pares de errores (de hecho y de derecho, y de tipo y prohibición) no son superponibles, no significan lo mismo. Siguiendo por ejemplo el delito previsto en el art. 340 del CP (hurto) el error de tipo es de hecho cuando recae sobre los elementos descriptivos (que se trata de una cosa mueble, un objeto de arte) y de derecho si recae sobre elementos normativos (ajenidad de la cosa, que refiere al derecho de propiedad). Con este ejemplo -dice Langón- se puede apreciar la artificiosidad de la distinción entre error de hecho y de derecho por cuanto todo en el artículo 340 del Código Penal como todo lo que aparece descripto en una ley se convierte en elemento jurídico, precisamente cuando la norma lo define, porque también en esencia "cosas" y "mueble", son elemento de derecho, elementos jurídicos. La definición de error de hecho prevista en el art. 22 del CP ("el error de hecho que versare sobre las circunstancias del delito exime de pena, salvo que, tratándose de ese delito, la ley castigare la simple culpa") se adecua perfectamente a la calificación de error de tipo que formula la doctrina, es perfectamente compatible con esta categoría, y por tanto, el error de hecho (de tipo) excluye el dolo. El propio Irureta en la nota explicativa del art. 22 dice que: "el error anula el dolo, pero deja subsistente la culpa". El error de hecho es en verdad un error de tipo, porque recae sobre "las circunstancias constitutivas del delito, es decir, sobre los supuestos de hecho del tipo objetivo ${ }^{123}$.

Los errores de carácter invencible o inevitable suponen la inexistencia de culpa y tienen como efecto la impunidad de la conducta, el sujeto no resulta responsable. Por el contrario, si se produjo un desconocimiento de la antijuridicidad (error de prohibición), pero el mismo podría haberse evitado actuando con mayor cuidado, nos hallamos ante un error de prohibición vencible o evitable. En estos casos la culpabilidad subsiste en la medida en que concurre el error; ésta disminuye y en consecuencia se atenúa la pena ${ }^{124}$. El error, aunque vencible, siempre elimina el dolo, por lo que si la infracción se castiga a título doloso, no hay infracción por inexistencia de culpa ${ }^{125}$. El reconocimiento generalizado de la sanción por imprudencia reduce severamente el ámbito de aplicación

\footnotetext{
${ }^{122}$ López López, "El principio de culpabilidad ...: 256.

${ }^{123}$ Langón, Manual ..., 252.

${ }^{124}$ López López, “El principio de culpabilidad ...: 279.

${ }^{125}$ López López, “El principio de culpabilidad ...: 280.
} 
del error, particularmente el de prohibición, circunscribiéndolo a aquellos casos en los que éste tuviera carácter inevitable o insuperable ${ }^{126}$.

\section{El error de hecho en materia tributaria}

No obstante ser ésta la posición dominante en el derecho penal, en materia tributaria (razonamiento que extendemos a la materia aduanera) el error evidente no podría ser reconducido sin más al error de tipo o al error de prohibición. Nótese que la categoría "error evidente" en el derecho aduanero tiene una profunda singularidad, conforme se ha explicado ${ }^{127}$. Comprende en nuestro concepto no sólo al mero error material, sino también al error de hecho y aún al error de derecho.

Así, en la doctrina tributaria García Novoa ha dicho que conceptuar al error de hecho de esta forma (introduciendo esta categoría en el error de tipo), lo reduciría a supuestos casi episódicos, porque, en la mayoría de los casos, el error en la apreciación de los hechos irá acompañado de equivocaciones en la vigencia temporal de las normas, ámbito espacial, o, en suma, de calificación jurídica de hechos o datos. Una postura como ésta supone reducir el error de hecho en la apreciación de la realidad sobre la cual se va a aplicar la norma a su mínima expresión, entendiéndose que cuando la apreciación de los hechos supone involucrar normas jurídicas, aún sin necesidad de interpretación alguna, no estaríamos ya ante errores materiales o de hecho, sino ante errores en la aplicación de normas jurídicas ${ }^{128}$.

Basándose en la jurisprudencia española, el citado autor ha dicho que el error de hecho es aquel para cuya comisión no se precisa de raciocinio alguno y que ha de ser evidente por sí mismo, patente, claro y manifiesto. La concreción más importante de este tipo de error es el error material, que versa sobre una cosa, hecho o suceso o, lo que es lo mismo, sobre una realidad independiente de toda opinión. Se emplea a veces en forma acumulativa la expresión "errores materiales, de hecho y aritméticos", destacando el autor citado que los errores aritméticos, por su carácter incontrovertible, habría que calificarlos como un grupo especial de errores de hecho ${ }^{129}$. García Novoa concluye que:

\footnotetext{
${ }^{126}$ López López, “El principio de culpabilidad ...: 281.

127 Supra Cap. II.

128 César García Novoa, La devolución de ingresos tributarios indebidos (Madrid: Instituto de Estudios Fiscales, Marcial Pons, 1993), 112.

${ }^{129}$ García Novoa, La devolución, 112-113.
} 
Nos hallamos pues, ante errores ostensible y evidentes y que, al recaer sobre cuestiones de hecho no susceptibles de controversia jurídica, se ponen de manifiesto al margen de todo criterio e interpretación jurídica, bien al deducirse del contexto general del acto jurídico o declaración a la que afectan -error material-, bien por su evidencia matemática - error de hecho aritmético ${ }^{130}$.

El error de hecho puede ser rectificado sin necesidad por tanto de un nuevo acto administrativo, no requiere la anulación de la liquidación sobre la que el error recae y la adopción de una nueva, sin que suponga nueva liquidación el resultado de practicar una rectificación que modifica la cuantía de la deuda tributaria ${ }^{131}$.

Meilán Gil, analizando la jurisprudencia del Tribunal Supremo de España, expresa que el error de cuenta (error aritmético) consiste en meras equivocaciones en las operaciones aritméticas, permaneciendo inalterados los datos. Por ejemplo, en una expropiación forzosa, se toma como única medida de un sótano la de 16 metros cuadrados, cuando consta en la hoja de aprecio que sus medidas eran 10 por 4 de altura, o sea 160 metros cúbicos.

El error de cuenta y el material han de constar inequívocamente en la documentación que consta en el expediente, pudiendo, además ser advertido tanto por la Administración como por el interesado.

Cuando exista duda o cuando el error se ponga de manifiesto por comprobación de hechos de los que no hay constancia en el expediente, el error, técnicamente hablando, no sería material sino de derecho. Ello, porque el error en este caso supone un enjuiciamiento de la situación de hecho. En un caso de expropiación forzosa, el documento que se estima correcto (el plano de clasificación) no constaba desde el primer momento y es posterior al trámite de información pública. No se trata de un error de hecho si no es manifiesto, y supone una decisión de enjuiciamiento de la situación de hecho.

Hay error de derecho siempre que se realice una operación de calificación jurídica; equivale a aplicación inadecuada de una norma. Es error de derecho haber declarado la Dirección Nacional de Viviendas de primera categoría viviendas que, inspeccionadas por el arquitecto del Ministerio de Viviendo se comprobó que no tenían las condiciones

\footnotetext{
${ }^{130}$ García Novoa, La devolución, 113-114.

${ }^{131}$ García Novoa, La devolución, 114-115.
} 
de construcción exigidas. El error cometido en la calificación inicial no era de hecho sino de concepto ${ }^{132}$.

Concluye el citado autor que la nota característica del error material o de hecho (identifica por tanto al error de hecho con el error material) es su carácter de máxima evidencia. El error material se comprueba; el error iuris se aprecia. Pero se afana en separar dos conceptos y es que no siempre que el error se descubra por simple comprobación se está ante un error de hecho. Si el error se descubre del mero examen de los datos contenidos en el expediente, existirá error de hecho. Si el error se comprueba con operaciones de comprobación al margen del expediente, existirá una labor de apreciación que nos aleja del concepto de error de hecho ${ }^{133}$. Otros autores prefieren circunscribir el error material solamente al que se descubra por la simple comprobación de los antecedentes documentales y puede ser corregido; y en cambio, reservan el concepto de error de hecho al error material que no puede ser corregido ${ }^{134}$. Siguiendo este criterio, y en un párrafo que interesa mucho a los efectos de este trabajo, Meilán Gil refiere a la rectificación de errores en materia arancelaria (en el derecho español), y transcribe el art. 113 de las Ordenanzas aprobadas por Decreto de 17 de octubre de 1947. Conforme a esta disposición, las reclamaciones por error en la liquidación o en el pago, podrán alegarse en el plazo de un año a contar desde la fecha en que se haya verificado aquél. En igual plazo a contar desde el día de la exacción, podrán alegarse las que versen sobre derechos mal exigidos por equivocaciones comprobables en el aforo o en los documentos que acompañen a las declaraciones. El derecho a hacer cualquiera de estas reclamaciones es mutuo para las dos partes, o sea, la Hacienda y los adeudantes.

En referencia a los actos emanados de la Administración, la doctrina española ha expresado que lo que sucede es que en el caso de error material (ya sea se le identifique

132 José Luis Meilán Gil: "Delimitación conceptual del error material y de cuenta", Revista de Administración Pública Numero 55 (Enero/Abril 1968, CEPC - Centro de Estudios Políticos y Constitucionales - Madrid, 155-159). En el mismo sentido, Joana M. Socías Camacho, "Error material, error de hecho y error de derecho. Concepto y mecanismos de corrección", Revista de Administración Pública No. 157, CEPC Centro de Estudios Políticos y Constitucionales (enero/abril 2002): 168-169.

${ }^{133}$ Meilán Gil, “Delimitación ...: 161.

${ }^{134}$ Socías Camacho, "Error material ..., 166. 
o no con el concepto de error de hecho susceptible de rectificación), los actos administrativos que contienen un error de este tipo son actos cuya declaración jurídica en sí misma considerada es perfectamente válida; lo que ocurre sin embargo, es que se produce una anomalía en la exteriorización de esa declaración jurídica que provoca desarmonía entre la declaración y su manifestación externa. Es decir, se trata de errores que no afectan a la auténtica voluntad administrativa, que es racional e indiscutiblemente deducible de sus precedentes documentales y que sólo inciden en la exteriorización de la declaración de voluntad. Estos errores por tanto pueden ser rectificados con la intención de adecuar la manifestación externa de la declaración a la verdadera voluntad, eliminando de sus actos, por tanto, todos aquellos elementos que alterna la exteriorización de esta. En suma, la declaración de voluntad administrativa no debe tener efectos no queridos por la Administración, como consecuencia de un simple error material en su manifestación externa. ${ }^{135}$

La posibilidad de rectificación de estos errores no requiere, en concepto de la doctrina, la anulación de la liquidación tributaria anterior. Si bien se modificaría la liquidación, el resultado de practicar una rectificación que modifica la cuantía de la deuda tributaria no sería propiamente hablando una "nueva liquidación". Esto es que el error de hecho, rectificado, supone la conservación del acto inicial de liquidación ${ }^{136}$. En el mismo sentido se ha dicho que uno de los requisitos configuradores del error material o de hecho es que:

(...) no padezca la subsistencia del acto administrativo, es decir, que no se genera la anulación o revocación del mismo en cuanto creador de derechos subjetivos, produciéndose uno nuevo sobre bases diferentes y sin las debidas garantías para el afectado pues el acto administrativo rectificador ha de mostrar idéntico contenido dispositivo, sustantivo y resolutorio que el acto rectificado, sin que pueda la Administración, so pretexto de su potestad rectificadora de oficio, encubrir una auténtica revisión, pues ello entrañaría un fraude de ley, constitutivo de desviación de $\operatorname{poder}^{137}$.

\footnotetext{
${ }^{135}$ Socías Camacho, "Error material ..., 167-168.

${ }^{136}$ García Gómez, “La simple negligencia....: 114-115.

${ }^{137}$ Socías Camacho, "Error material ..., 169.
} 


\section{Conclusiones sobre el error evidente en el Derecho Aduanero}

\section{El error evidente como error que "desaparece" al considerar la declaración aduanera en su conjunto}

Este error, como se ha afirmado, es el que surge en forma palmaria (clara, patente, manifiesta) de una lectura atenta de la declaración (permiso) o de la lectura de la documentación complementaria. Ya se ha visto que este error tiene la particularidad de que se comete en ocasión de la declaración aduanera, acto complejo integrado no sólo por la declaración de detalle, sino también por los documentos complementarios que le sirven de base; así, la consideración de la "declaración informativa" en su conjunto puede revelar la evidencia del error.

En este sentido podemos afirmar que el error evidente en el derecho aduanero es susceptible de "autocorregirse" si el mismo surge de la declaración en su conjunto (considerada como un todo). En este sentido, el error evidente puede ser tanto de hecho como de derecho, ya que se comprueba (error de hecho) o se aprecia (error de derecho). Siempre, claro está que esa evidencia del error surja de la propia declaración aduanera considerada como un todo y no de elementos externos a la misma.

Tampoco el error evidente resulta punible si se acude a las categorías del error de tipo y del error de prohibición (que entendemos no son trasladables sin más al derecho infraccional aduanero). Si el error de tipo consiste en una falta de representación o una incorrecta representación de un elemento del tipo infraccional, podemos afirmar que una persona supuestamente imputable puede haberse representado perfectamente los elementos del tipo, saber en qué consisten, y sin embargo cometer un error evidente.

En cuanto al error de prohibición, recordemos que existe no sólo cuando el sujeto se representa positivamente que no actúa de modo antijurídico, sino ya cuando le falta la conciencia de la antijuridicidad sin que hubiera reflexionado nunca sobre tal posibilidad. Resulta muy complejo trasladar estos conceptos al derecho sancionatorio aduanero. Pero lo que puede decirse es que, en el caso del error evidente, la eventual falta de representación o ausencia de reflexión sobre la antijuridicidad deviene irrelevante, ya que la evidencia del error hace de éste una circunstancia que impide la responsabilidad, en la medida en que, vista en su conjunto, la declaración se "autocorrige", no es "ni 
verdadera ni falsa" como dice la doctrina y jurisprudencia argentina. Jurisprudencia que expresamente entiende que el error evidente también puede ser de derecho: se trata del caso señalado en párrafos precedentes, en que una misma persona era exportador e importador, y no correspondía el pago de reembolso alguno por la exportación, improcedencia que surgía de la propia declaración aduanera ${ }^{138}$.

En sentido similar -extensión del error evidente al error de derecho- podrían citarse algunos fallos judiciales de la justicia especializada de nuestro país en materia aduanera. Se trató de pronunciamientos en los cuales se rechazó la pretensión de configurar una infracción en virtud de un supuesto error en el certificado de origen que en opinión de la Aduana descalificaba el mismo. En un caso el certificado de origen tenía una errónea mención a la nomenclatura aplicable (se hacía referencia a la NANDINA y correspondía la NALADISA); en el otro caso se citaba en el certificado de origen una norma de origen equivocada, y no se incluía en el campo 14 del documento la referencia exacta a un Acuerdo de Complementación Económica. En ambos casos, el denunciante -la Aduana- no cuestionó que el origen fuera el declarado, simplemente su pretensión fue de descalificar el certificado y por tanto invalidar el origen (aun reconociendo que era correcto el declarado). En ambos casos, la justicia especializada, entendió que el error era "formal" en tanto no afectaba la calificación del origen y era fácilmente subsanable, por lo que no podía existir infracción ${ }^{139}$. Si bien las Resoluciones judiciales no hicieron expresa mención al error evidente y su fundamento -como se explicó- radicó en el concepto de "error formal" propio de los Reglamentos de Origen vigentes en los Acuerdos Comerciales bajo el marco de la ALADI, no es menos cierto que en la defensa de los referidos casos se esgrimió la defensa del error evidente; éste parecía cierto, en la medida en que del contexto de toda la declaración el mismo surgía con toda claridad, y por otra parte la administración aduanera, sustancialmente, no discutía el origen declarado.

\section{El error evidente como error inculpable}

En adición a ello, lo cierto es que el error evidente, el que surge de la mera lectura de la declaración y su documentación complementaria, tiene un grado menor al error que normalmente se considera en materia penal o civil. En estas materias, el error es un quid

\footnotetext{
${ }^{138}$ Supra Cap. II, No. 5.

${ }^{139}$ Resoluciones del Juzgado Letrado de Aduana Nos. 1562/2016 de 11 de octubre de 2016 y 1638/2016 de 26 de octubre de 2016.
} 
positivo que importa cierto convencimiento implicando la presencia de nociones falsas, equivocadas o disparatadas, es decir, un saber mal, cuyo origen está en una falta de diligencia del declarante. En el error evidente, el declarante no tiene normalmente una noción falsa, no incurre en un saber mal (o al menos no incurre en un saber mal inexcusable). Tampoco incurre en una negligencia puesto que, si se considera a la declaración aduanera como un todo, no ha incurrido en ninguna conducta negligente que pueda causar un perjuicio ${ }^{140}$.

Una vez más, la consideración de la declaración como un "todo" que incluye una serie de documentos, de cuya lectura total se advierte el error evidente en la declaración, determina que la diligencia del declarante no se vea menoscabada. Si, a pesar de haber errado en la declaración "pura", ha aportado todos los elementos que, considerados conjuntamente, permiten a la autoridad aduanera corroborar y determinar sin hesitación alguna cuál es el alcance de la declaración, resulta evidente que no ha sido negligente. La consideración de la declaración en su totalidad, entonces, permite advertir que el error es "evidente" y puede ser relevado de la mera lectura de todos los documentos, de la cual se deriva la exacta voluntad del declarante. Una solución diferente -castigar ese tipo de "errores"- podría determinar que la culpa se mida con el metro de la "culpa levísima", que supone exigir una diligencia superior a la media, tomándose como modelo al hombre diligentísimo o muy prudente y diligente, dotadísimo, un excelente pater familias; se respondería por los descuidos de importancia mínima, casi imperceptibles, perdonables. Como hemos visto, esta concepción está desterrada del derecho civil, tributario y penal, en cuyos ámbitos la culpa levísima no es culpa y el

${ }^{140} \mathrm{O}$, al menos, no se llega al parámetro de la negligencia "grave" que exige el artículo VIII.3 del Acuerdo General sobre Tarifas y Comercio (GATT) de 1994 en forma programática: "Ninguna parte contratante impondrá sanciones severas por infracciones leves de los reglamentos o formalidades de aduana. En particular, no se impondrán sanciones pecuniarias superiores a las necesarias para servir simplemente de advertencia por un error u omisión en los documentos presentados a la aduana que pueda ser subsanado fácilmente y que haya sido cometido manifiestamente sin intención fraudulenta o sin que constituya una negligencia grave". El GATT es un acuerdo aprobado por la ley No. 16.671 de 13 de diciembre de 1994, en el marco de la aprobación de los acuerdos establecidos en el Acta Final de Marrakech que pone fin a la Ronda Uruguay, y por los cuales se crea la Organización Mundial de Comercio. 
límite de la responsabilidad es la llamada culpa leve (o culpa media), ligado a la diligencia de un buen padre de familia.

Inclusive la doctrina tributaria ha afirmado que resulta ilógica la sanción en los casos de una interpretación errónea razonada y razonable o por inexactitudes o defecto de la misma naturaleza en la declaración, señalando que la conclusión no puede ser otra que la falta de culpabilidad, ni siquiera a título de simple negligencia en lo que se refiere a la repercusión que en las bases imponibles, y por ende, en las cuotas correspondientes pudo tener el error, cuando se aportaron todos los datos para su determinación como resultó de la liquidación provisional paralela practicada, en la que tan sólo se evidencia como discrepancia la liquidación presentada, evidenciándose de esta forma la inexistencia de intención de defraudar o de evadir las obligaciones fiscales ${ }^{141}$. Cuando el sujeto agente declara la totalidad de los elementos necesarios para que la Administración, en uso de sus funciones, pueda efectuar la correcta liquidación del tributo, pero ha cometido irregularidades objetivamente disculpables en los elementos de derecho de la autoliquidación, ha observado la diligencia que le es exigible ${ }^{142}$.

\section{Otras consideraciones}

Señalemos por último, como elementos que pueden, en forma adicional, justificar la no punibilidad del error evidente. En primer lugar, el principio de proporcionalidad de la pena, esto es que la misma debe estar en consonancia con el grado y la gravedad de la infracción cometida. Se trata de un principio general de derecho sancionatorio, recogido inclusive en el más moderno instrumento jurídico de fuente internacional ${ }^{143}$. En

${ }^{141}$ García Gómez, "La simple negligencia...: 102, nota al pie.

${ }^{142}$ García Gómez, "La simple negligencia...: 105.

${ }^{143}$ Los Miembros de la OMC aprobaron en la Conferencia Ministerial de Bali (2013) el Acuerdo de Facilitación del Comercio ("AFC" o "TFA" según su sigla en inglés), que entró en vigor como enmienda al Acuerdo de Marrakech (por el que se establece la OMC) el 22 de febrero de 2017, luego de su ratificación por dos tercios de Miembros de la OMC; y como todo instrumento que forma parte de la OMC, es de aplicación obligatoria por sus Miembros. Este Acuerdo contiene previsiones para hacer más expeditivo el movimiento, libramiento y puesta en libre circulación de bienes, incluyendo bienes en tránsito. También establece medidas para la efectiva cooperación entre las aduanas y otras autoridades competentes en materia de facilitación del comercio y cumplimiento de estándares aduaneros. Asimismo, contiene previsiones 
segundo lugar, el examen cuidadoso del tipo infraccional, puede revelar que la infracción en cuestión se castigue solamente a título de dolo. Y el error, excusable o no, siempre elimina el dolo.

Finalmente, en tercer lugar, y siguiendo con variantes a la doctrina española que se ha citado con anterioridad, la declaración que contiene un error evidente es un acto cuya declaración jurídica en sí misma considerada en su totalidad es perfectamente válida; lo que ocurre, sin embargo, es que se produce una aparente anomalía en la exteriorización de esa declaración jurídica que provoca desarmonía entre la declaración y su manifestación externa. Es decir, se trata de errores que no afectan a la auténtica voluntad del declarante que es racional e indiscutiblemente deducible de sus precedentes documentales y que sólo inciden en la exteriorización de la declaración de voluntad. Estos errores por tanto pueden ser rectificados con la intención de adecuar la manifestación externa de la declaración a la verdadera voluntad, eliminando de sus actos, por tanto, todos aquellos elementos que alteran la exteriorización de esta. En suma, no puede atribuirse a la declaración aduanera efectos no queridos por el declarante, como consecuencia de un simple error en su manifestación externa ${ }^{144}$.

Contribución: $100 \%$ del autor

\section{Bibliografía}

Aftalión, Enrique R., José Vilanova y Julio Raffo. Introducción al Derecho, $5^{\text {a }}$ edición, Buenos Aires, Abeledo Perrot, 2009.

Agostino, Sol y Natalia Acosta Casco, Las eximentes de responsabilidad en materia de infracciones tributarias, Revista Tributaria No. 248 (Instituto Uruguayo de Estudios Tributarios) Tomo XLII (set.-oct. 2015): 717-747.

Albarracín Héctor G. y Guillermo Vidal Albarracín. El Despachante de Aduana, Buenos Aires, Guía Práctica S.A. y Ediciones IARA S.A., 2016.

para asistencia técnica y desarrollo de capacidades en estas áreas. Lo cierto es que Uruguay fue uno de los Miembros que ratificó dicho Acuerdo y contribuyó a su puesta en vigencia; así, el AFC fue internalizado por la ley No. 19.414 del 30 de junio del 2016.

144 Hemos adaptado las reflexiones de Socías Camacho (167-168) a la declaración aduanera. 
Alsina, Mario A., Enrique C. Barreira, Ricardo Xavier Basaldúa, Juan P. Cotter Moine y Héctor G. Vidal Albarración. Código Aduanero Comentado, 3 tomos (completado y actualizado por Enrique C. Barreira, Ricardo Xavier Basaldúa, Héctor G. Vidal Albarracín, Juan P. Cotter (h.), Ana L. Sumcheski y Guillermo Vidal Albarracín (h.), Buenos Aires, AbeledoPerrot, 2011.

Barreira Enrique Carlos y Héctor Guillermo Vidal Albarracín, La responsabilidad en las infracciones aduaneras, Revista La Ley (Buenos Aires) 1989, A, Sec. Doctrina, 925-960. Barreira, Enrique C. Código Aduanero. Comentarios. Antecedentes. Concordancias, Tomo II-A, Buenos Aires, Abeledo-Perrot, 1986.

Barreira, Enrique C. La relación jurídica tributaria y la relación jurídica aduanera, Revista de Estudios Aduaneros (Instituto Argentino de Estudios Aduaneros), Año XVIII, No. 18 , (1 ${ }^{\circ}$ sem. - 2007): 55-74.

Barreira, Enrique C. La solicitud de destinación aduanera y la declaración aduanera, Revista de Estudios Aduaneros (Instituto Argentino de Estudios Aduaneros), Año XI, No. 14 (2000 - 1er. Sem. 200): 115-145.

Barreira, Enrique C. Sistema y metodología del Código Aduanero Argentino, en Estudios de Derecho Aduanero (homenaje a los 30 años del Código Aduanero), Juan Patricio Cotter (coordinador), Buenos Aires, AbeledoPerrot, 2011, 21-38.

Basaldúa, Ricardo Xavier. La Aduana: concepto y funciones esenciales y contingentes, Revista de Estudios Aduaneros (Instituto Argentino de Estudios Aduaneros), Año XVIII, No. 18 ( $1^{\circ}$ sem. 2007): 41-42.

Basaldúa. Ricardo Xavier Los principios jurídicos del control aduanero modernizado en el tráfico transfronterizo contemporáneo, El Derecho. Diario de Doctrina y Jurisprudencia, Buenos Aires, martes 26 de noviembre de 2013, No. 13.371, Año LI: 18.

Berro, Federico, Criminalización de las infracciones tributarias, Revista Tributaria, Tomo XXV, No. 144 (mayo-junio 1998): 325-371.

Berro, Federico. Los ilícitos tributarios y sus sanciones, $2^{\mathrm{a}}$ edición, Montevideo, FCU, 1995.

Cairoli Martínez, Milton Hugo. El Derecho Penal Uruguayo y las nuevas tendencias penales", Tomo I (La Ley - El Delito), Montevideo, FCU, 2000.

Camaño Viera, Diego. El delito de abuso de funciones en la nueva jurisprudencia de la Suprema Corte de Justicia, Revista de Derecho Penal No. 17 (2ª época - Abril 2008): 157-167. 
Cotter, Juan Patricio. Las infracciones aduaneras, Buenos Aires, Abeledo Perrot, 2011. Delpiazzo, Carlos E. y Graciela Ruocco (directores), Tratado Jurisprudencial y Doctrinario (actos y contratos de la administración). Montevideo, La Ley Uruguay, 2013.

Fernández Lalanne, Pedro E. Comentarios al Código Aduanero. $2^{\text {a }}$ Edición Actualizada, Buenos Aires, Guía Práctica del Exportador e Importador, 1985.

Ferrari, Rossana La responsabilidad prevista en el artículo 287 de la ley 13.318 Régimen represivo aduanero-, ¿es objetiva?, Revista de comercio Exterior y Aduana, FCU No. 3 (1997): 67-72.

Ferrere, Daniel, Derecho sancionatorio y procesal en Jornadas de derecho tributario aduanero (Derecho sancionatorio y procesal), Revista Tributaria (Instituto Uruguayo de Estudios Tributarios), No. 96, Tomo XVII (Mayo-junio 1990): 269-291.

Ferro, Carlos A. y Francisco M. Ferro. Código Aduanero comentado. $2^{\mathrm{a}}$ edición actualizada, Buenos Aires, Ediciones Depalma, 1990.

Gamarra, Jorge. Tratado de Derecho Civil Uruguayo, Tomo XIX, Tercera Parte, Responsabilidad Civil Extracontractual - Volumen 1º, Montevideo, FCU, 1981.

García Gómez Antonio J. La simple negligencia en la comisión de infracciones tributarias, Madrid, Marcial Pons, 2002.

García Novoa César. La devolución de ingresos tributarios indebidos, Instituto de Estudios Fiscales, Madrid, Marcial Pons, 1993.

González Berro, Raúl, Las inhabilitaciones y suspensiones de los operadores privados en el Derecho Aduanero en Memorias del Primer Encuentro Iberoamericano de Derecho Aduanero, Guadalajara, Jal. México, IIFA, 2005: 116-122.

González Berrro, Raúl, Breve análisis de algunas situaciones relacionadas con las infracciones de valor, Revista de Comercio Exterior y Aduana, FCU, No. 4 (1998): 7178.

González Bianchi, Pablo, El valor en aduana (la valoración de las mercaderías en el sistema GAT/OMC). Montevideo, Universidad de Montevideo (tomo 1, 2003 y tomo 2, 2010).

González Cuñarro, Ariosto, Diferencia de Valor, Revista de Comercio Exterior, Año I, No. 4 (Enero 1977): 26-27.

González Cuñarro, Ariosto, Error aritmético y defraudación de valor, La Justicia Uruguaya, tomo 85, comentario al caso No. 9758, 61- 68. 
González Cuñarro, Ariosto, La declaración aduanera de las mercaderías en los países del MERCOSUR y en la Unión Europea, Revista Tributaria (Instituto Uruguayo de Estudios Tributarios), No. 194 Tomo XXXIII (setiembre-octubre 2006): 593-617. Este trabajo fue publicado también en la Revista de Estudios Aduaneros (Instituto Argentino de Estudios Aduaneros, No. 17, Año XVII (2005 y 2006): 55-74.

Labandera, Pablo, La infracción administrativa de contravención aduanera”. Su régimen jurídico a la luz del Derecho nacional, Revista Tributaria (Instituto Uruguayo de Estudios Tributarios), Tomo XL, No 236 (setiembre-octubre 2013): 833-854.

López Carmelo, Raúl Guillermo y Gabriel Darío Jarque, Curso de Derecho Penal, Bahía Blanca, Universidad Nacional del Sur, 2004.

López López, Hugo, El principio de culpabilidad en materia de infracciones tributarias, Asociación Española de Asesores Fiscales, Navarra, ARANZADI Thomson Reuters, 2009.

Lorenzo de Viega Jaime, Susana, Naturaleza de la infracción y sanción administrativa, en Tratado Jurisprudencial y doctrinario (Actos y contratos de la Administración), en Carlos E. Delpiazzo y Graciela Ruocco (dir.), Tomo II, La Ley Uruguay (2013): 687700 .

Lorenzo de Viega Jaime, Susana, Sanciones administrativas. Montevideo, Editorial BdeF, 1996.

Maljar, Daniel E., El derecho administrativo sancionador, Buenos Aires, AD-HOC, 2004.

Martínez Roldán, Luis y Jesús A. Fernández Suárez, Curso de teoría del derecho, $2^{\mathrm{a}}$ edición, Barcelona, Ed. Ariel, 1999.

Meilán Gil, José Luis, Delimitación conceptual del error material y de cuenta, Revista de Administración Pública (CEPC, Madrid), No 55 (Enero/Abril 1968): 151-188. http://www.cepc.gob.es/publicaciones/revistas/revistaselectronicas?IDR=1\&IDN=55\&I $\underline{\mathrm{DA}=22551}$. Consultada en marzo de 2019.

Mir Puig, Santiago, Derecho Penal, Parte General, 9. Edición (2ª reimpresión), Montevideo - Buenos Aires, BdeF, 2015.

Nieto, Alejandro, Derecho Administrativo Sancionador. $5^{\text {a }}$ Edición totalmente reformada, Madrid, TECNOS, 2012 (reimpresión 2015).

Núñez, Ricardo C., Manual de Derecho Penal, Parte General, 4a. Edición actualizada, Córdoba: Marcos Lerner, 1999. 
Rosello, Hugo M., Declaración aduanera de las mercaderías, La Aduana Uruguaya, Año LVI, No. 735 (Dic. 1969): 3491-3495.

Roxin, Claus, Derecho Penal General. Tomo I (Fundamentos. La estructura de la Teoría del Delito), traducción de la 2a. edición alemana (reimpresión), Madrid, Thomson - Civitas, 2003.

Ruocco, Graciela, Principios de legalidad, tipicidad y de prescripción en materia de actividad sancionatoria de la Administración, Carlos E. Delpiazzo y Graciela Ruocco (dir.): 700-742.

Shaw José Luis, El error como eximente de responsabilidad en materia de infracciones tributarias, Revista Tributaria (Instituto Uruguayo de Estudios Tributarios), No. 47, Tomo IX (marzo-abril 1982): 111-136.

Silva Forné, Diego. Infracción fiscal, infracción administrativa y derecho penal. Derecho Penal, Hacienda y Administración Pública en Mariana Malet Vazquez, Diego Silva Forné (coord.), Perspectivas en derecho nacional, internacional y comparado Montevideo, FCU, 2008.

Socías Camacho, Joana M., Error material, error de hecho y error de derecho. Concepto y mecanismos de corrección, Revista de Administración Pública (CEPC-Madrid), No. 157 (enero/abril 2002): 157-211.

http://www.cepc.gob.es/publicaciones/revistas/revistaselectronicas?IDR=1\&IDN=155\& $\underline{\text { IDA=24419. }}$. Consultada en marzo de 2019.

Valdés Costa, Ramón, Instituciones de Derecho Tributario, Buenos Aires, Depalma, 1992.

Vidal Albarracín, Héctor G., El bien jurídico tutelado como medio eficaz de armonización internacional de los ilícitos aduaneros, Revista de Estudios Aduaneros (Instituto Argentino de Estudios Aduaneros), No. 17, Año XVII (2005 y 2006): 29-36.

Welzel, Hans, Derecho Penal. Parte General, Buenos Aires, Roque Depalma Editor, 1956.

Zaffaroni, Raúl Eugenio, Alejandro Alagia y Alejandro Slokar. Derecho Penal. Parte General, 2ª edición, Buenos Aires, EDIAR, 2002. 